\title{
Caring but sharing unintentionally: Lobbying for innovation and the leakage of knowledge*
}

\author{
Michael Park
}

August 27, 2022

\begin{abstract}
When firms engage in lobbying, the primary outcome they seek is beneficial regulatory change. However, prior literature suggests that there may also be a secondary outcome to lobbying - the leakage of knowledge to competitors. In this paper, I explore the leakage of technological knowledge when firms lobby for innovation-related regulations and the strategic response of competitors to the leakage. Based on field interviews and existing studies, I argue that when a firm is involved in lobbying, competitors are able to learn about the lobbying firm's technologies through third parties and the policies for which the lobbying firm advocates. Furthermore, I propose that lobbying is especially leaky when external lobbyists, whose interests are misaligned with the firm, are involved. To test this theory, I use a unique dataset on U.S. firms that engaged in lobbying for their innovation and the patents applied for by those firms. I utilize a machine learning approach, Doc2Vec, on the text of patents to directly detect knowledge leakage in the strategic response of competitors (Figure 1). The results suggest that lobbying firms' patents, compared to patents from non-lobbying firms, are associated with 4 more imitative patents generated by competitors. Moreover, increases in external lobbying is positively linked to imitation from competitors while inhouse lobbying is not. Overall, this paper documents a technological risk inherent to coordinating a firm's innovation activity with its political strategy.
\end{abstract}

*E-mail park1892@umn.edu. I thank Mary Benner, Russell Funk, Aseem Kaul, Jiao Luo, Bill McEvily, Patrick McLaughlin, Cameron Miller, and Aks Zaheer for their feedback on earlier drafts. I also thank participants of Academy of Management Annual Conference; Conference on Artificial Intelligence, Machine Learning, and Business Analytics; Consortium on Competitiveness and Cooperation Doctoral Conference; Great Lakes Entrepreneurship Network Conference; Industry Studies Association Annual Conference; NonMarket Strategy Research Community Doctoral Conference; Society for Institutional \& Organizational Economics Annual Conference; Strategic Management Society Annual Conference; University of Minnesota's Strategic Management and Entrepreneurship department seminars; and ZEW Mannheim's seminar for their feedback. Furthermore, I thank Patrick McLaughlin and Insong Kim's generosity regarding RegData and LobbyView, respectively. I also acknowledge funding support from the SRF Dissertation Research Grant, Mercatus QuantGov Grant, University of Minnesota's Doctoral Dissertation Fellowship, and Carlson Dissertation Fellowship. Finally, I thank everyone who agreed to be interviewed for this project. 


\section{Introduction}

The nonmarket literature has noted that firms often try to change their institutional environments (Hillman \& Hitt 1999, Dorobantu, Kaul \& Zelner 2017, Funk \& Hirschman 2017). One of the activities through which firms attempt to directly shape the regulatory environment is lobbying (de Figueiredo \& Richter 2014, Jia 2018, Bombardini \& Trebbi 2020). Lobbying can be understood as the act of strategically providing information to policymakers in order to be involved in the process of changing regulation (Grossman \& Helpman 2001, Hillman \& Hitt 1999, Werner 2015). Policymakers are often unable to keep up with the latest developments in the industry (e.g., Weber, Heinze \& DeSoucey 2008, Sine \& Lee 2009, Funk \& Hirschman 2014, Paik, Kang \& Seamans 2019). By delivering key information, firm lobbying can direct regulators' attention to current needs of the industry (Bernstein 1955, McCaffrey 1982, Ungson, James \& Spicer 1985, Jones 1999, 2003). For example, lobbied policymakers can facilitate the introduction of new products through regulatory decisions (Barber IV \& Diestre 2019, Diestre, Barber IV \& Santaló 2020). Therefore, firms can use lobbying to try to change regulations in ways that support their new activities. This often represents the intended outcome of firm lobbying.

However, there may also be an unintended outcome of lobbying. Lobbying involves firms exchanging various information with external lobbyists, competitors, as well as policymakers. During this process, firms may unintentionally leak knowledge to competitors (de Figueiredo \& Tiller 2001). Unintended knowledge leakage has been observed in other contexts where various parties within an industry also interact and share information, such as venture capital fundraising (Cox Pahnke, McDonald, Wang \& Hallen 2015), corporate investments in entrepreneurial ventures (Katila \& Chen 2008, Dushnitsky \& Shaver 2009), and mergers and acquisitions (Rogan 2014, Rogan \& Sorenson 2014). Moreover, the leakage of knowledge to competitors has been a noted feature of standard setting organizations ("SSO") (Toh \& Miller 2017, Ranganathan, Ghosh \& Rosenkopf 2018, Jones, Leiponen \& Vasudeva 2020)—which 
shares a key similarity to the lobbying context in that firms interact with each other to collectively shape their institutions. These existing studies on leakage find that when there is spillage of valuable knowledge, competitors can expropriate the knowledge, which in turn can be costly for the compromised firm (Cox Pahnke et al. 2015, Toh \& Miller 2017). Therefore, knowledge leakage could be a significant risk for lobbying firms.

Yet, no prior study has documented whether firm lobbying does systematically lead to knowledge leakage. In order to better understand this potential non-financial consequence of lobbying, I develop a theoretical framework on innovation lobbying and the leakage of technological knowledge. By innovation lobbying, I refer to efforts by firms to change existing regulations to allow their new technologies to be adopted by the industry in an appropriate manner (e.g., Hargadon \& Douglas 2001, Sine \& Lee 2009, Navis \& Glynn 2010, Barber IV \& Diestre 2019, Diestre et al. 2020). I choose to focus on the lobbying activity around innovations because existing literature has recognized that technological knowledge leakage can be critical for firms (Teece 1986, Katila \& Chen 2008, Ahuja, Lampert \& Novelli 2013). Put differently, if knowledge about firms' innovations leak when firms lobby for them, it would would represent a significant technological risk (Mansfield, Schwartz \& Wagner 1981, Mansfield 1985, Lieberman \& Montgomery 1988, Barney 1991, Anton \& Yao 2004) inherent to the political activity of lobbying. Currently, it is unclear whether knowledge leaks when firms lobby for their innovation.

Based on field interviews conducted over multiple years and insights from prior literature, I propose that fundamental lobbying interactions - such as communicating with politicians and advocating for policy - are leaky. Therefore, competitors are able to gain strategically valuable information about the lobbing firm, in particular the directions of technology to which the lobbying firm is committed (e.g., Ocasio 1997, Eggers 2012, Clough \& Piezunka 2020, Krieger 2021). Thus, I predict that lobbying for innovation will lead to the leakage of technological knowledge, which competitors will use to create highly similar technologies. Furthermore, I predict that external lobbyists, who are less focused on preventing leakage 
compared to inhouse lobbyists, are more likely to be the source of leakage. I test these predictions using a unique dataset on U.S. firms, which allows me to identify firms that engaged in lobbying to federal agencies making technology-related regulatory changes. I develop a new measure for knowledge leakage, a concept that has not been operationalized in prior studies, using a machine learning approach (i.e., Doc2Vec) on the abstracts of firms' patents (see Figure 1). Employing this measure, I find that lobbying is positively associated with imitative patenting from competitors. More specifically, lobbying firms' patents are associated with $4(21 \%)$ more imitative patents than the patents of non-lobbying firms. In addition, while inhouse lobbying is not positively linked to imitation, a $\$ 100,000$ increase in external lobbying is associated with 7 (30\%) additional imitative patents. Further analysis shows that patents with 7 more imitations are valued $\$ 49,000(0.45 \%)$ less, suggesting that the leakage during lobbying is a technological risk firms face. The results are robust to several measurement and identification concerns.

Overall, this study demonstrates that there is a tradeoff inherent to lobbying for innovations. When firms try to appropriate additional value from their technology by shaping the regulatory environment, they have to disclose information about their technology which can lead to imitation from competitors. In this way, the paper represents one of the first attempts to directly explore the link between corporate political action and innovation (e.g., Barber IV \& Diestre 2019, Diestre et al. 2020), an underexplored area of "integrated strategy" (Jia \& Mayer 2016, Ahuja, Capron, Lenox \& Yao 2018, Oberholzer-Gee \& Yao 2018). Therefore, the paper contributes to both the nonmarket strategy and innovation literatures. With respect to the nonmarket strategy literature, this paper sheds light on the process of lobbying, which had been treated as a "blackbox." Prior work on lobbying in the strategic management field tended to focus only on the inputs (e.g., lobbying expenditure or the decision to hire lobbyist) and firm outcomes (e.g., contract value or regulatory decisions) (e.g., Raffiee 2017, Barber IV \& Diestre 2019, Kim 2019, Diestre et al. 2020, Shi, Gao \& Aguilera 2021). In contrast, I directly explore an important intermediary process (e.g., knowledge leakage) of lobbying. This insight 
is essential to advance our understanding of the mechanisms underlying corporate political activities. I also contribute to the innovation literature. While recent studies investigating the effects of the political landscape on innovation focused on institutional changes that were understood to be exogenous to firm strategy (e.g., Arora, Belenzon \& Sheer 2021, Marx, Strumsky \& Fleming 2009, Balsmeier, Fleming \& Manso 2017), I demonstrate that nonmarket strategy firms choose to engage can influence innovation outcomes as well. In sum, this paper represents one of the first attempts to directly explore the Politics of Innovation-new frontiers at the intersection of political forces and new technologies (e.g., Park \& Funk 2022).

\section{Lobbying for Innovation}

In order to develop a theory on lobbying for innovation and knowledge leakage, I start by explaining why firms try to intentionally shape their institutional environments to benefit their new technologies. Subsequently, I propose that lobbying requires interactions which can be leaky. These discussions motivate the hypothesis about lobbying for innovation and knowledge leakage.

\section{The Intended Outcome of Lobbying}

\section{Regulatory change}

The institutional environment represents the rules of the game that influence how firms can and should behave (Aplin \& Hegarty 1980, North 1990, Scott 2013). Regulation, which represents a key part of the institutional environment, can evolve over time thereby changing the landscape of opportunities and threats firms face (Baysinger 1984, Jia \& Mayer 2016). Through regulations, policymakers attempt to control firms' behaviors in specific ways, largely in reaction to what firms have been doing in the past (Wilcox \& Shepherd 1975, Baysinger 1984, Meier 1985, Edelman \& Suchman 1997). Therefore, the regulatory framework tends to develop around existing activities rather than ones that may or may not come into existence in 
the future. Furthermore, policymakers are unable to instantaneously process new information due to cognitive limitations (Jones 1999, 2003, Jones \& Baumgartner 2005, Werner 2015). This means that regulation can often fail to keep pace with the latest developments of the industry (e.g., Weber et al. 2008, Funk \& Hirschman 2014). For this reason, many technologies that are new to the industry initially are deficient of a regulatory framework. (e.g., Hargadon \& Douglas 2001, Sine \& Lee 2009, Navis \& Glynn 2010).

Such lack of regulatory guidance on new technologies can create political, economic, and technological uncertainty about those innovations. For example, satellite radios lacked legitimacy at first because it was unclear if the new form of radio technology would be formally recognized by regulators (Navis \& Glynn 2010). Given the importance of the political approval of new technologies (Tushman \& Rosenkopf 1992, Geels 2004), without the assurance that the technology will become legitimate, new technologies lacking regulatory support can face significant political uncertainty. Innovations may also initially face economic uncertainty. When renewable energies were first introduced, the underlying technologies of renewables did not fit neatly into the existing regulatory framework (Sine \& Lee 2009, Sovacool 2009). This created uncertainty about the economics of renewable technologies. For example, there were inconsistent tax credit policies and a lack of regulatory guidance on what price the renewable energy should be sold for (Sovacool 2009). In addition to political and economic uncertainty, there may also be technological uncertainty. When electricity light was being commercialized for the first time, there was uncertainty about what configuration of the technology would be available in New York City. Edison wanted to install the systems of the new technology — such as electric wires - underground, just like other parts of existing utility technologies - such as gas pipes and water pipes (Hargadon \& Douglas 2001). However, only technologies that were considered to be a utility according to the existing regulation were allowed to be installed underground in New York City (Hargadon \& Douglas 2001, Silverberg 1967). It was unknown if and when electricity light would be considered a utility by industry regulators (Hargadon \& Douglas 2001, Silverberg 1967). In this way, when innovations are 
first introduced, they can face political, economic, and technological uncertainties due to the lack of regulatory guidance, which can be detrimental to the success of the new technology (Hargadon \& Douglas 2001, Sine \& Lee 2009, Sovacool 2009, Navis \& Glynn 2010).

However, subsequent regulatory changes can reduce the uncertainty by introducing the innovation into the regulatory framework (Geels 2004, Geels, Sovacool, Schwanen \& Sorrell 2017, Geels, Sareen, Hook \& Sovacool 2021). This is a major part of what firms seek to accomplish when they lobby for their innovations. Unlike policymakers who lack detailed knowledge about the new technologies to understand what the appropriate regulatory changes may be, firms are perpetually involved in the nexus of industry regulations and their own technologies. They are often willing and ready to conduct research to gather information that can be helpful for shaping the regulatory environment (Grossman \& Helpman 1994, Jia 2018, Hall \& Deardorff 2006). Prior research on innovation has emphasized the importance of the regulatory environment for the success of new technologies (Teece 1986, Anderson \& Tushman 1990, Tushman \& Rosenkopf 1992). Therefore, from the firms' perspective, lobbying represents a way in which they can share information with regulatory agencies in order to change regulations to be more accommodating of industry innovations. Concurrently, for policymakers, regulatory agencies can learn about recent developments in the industry through firms' lobbying activities (Edelman \& Suchman 1997, Hillman \& Hitt 1999), including new technologies. This informational role of lobbying is clearly illustrated in the following quote from an interview with a lobbyist in the energy sector.

"New technologies, products, and business models often do not fit within the existing regulations. Therefore, regulations tend to lag behind. Lobbying is one of the ways in which the industry can help inform policymakers about new regulatory models needed for changing business models."

As the lobbyist indicates, firm lobbying can serve the purpose of providing useful information to regulatory agencies. Because regulations tend to be focused on existing activities, policymakers can use the information from firms to update the regulatory framework. Ac- 
cording to the lobbyist, some of the information that lobbyists deliver will be about new technologies in the industry.

However, policymakers at federal agencies are not likely to be receptive to all types of lobbying efforts from firms (McCaffrey 1982, Ungson et al. 1985). Regulatory agencies will be discerning in the what information they choose to heed. Public agencies ascribe to the institutional norm of serving the greater society rather than an individual interest (Denhardt \& Denhardt 2000, Hiatt \& Park 2013, Grandy \& Hiatt 2020). Moreover, interviews suggest that firms can and do take agencies to court at times for making regulatory changes that are deemed to violate their public service role. Therefore, regulatory agencies will try to make changes that benefit the industry overall rather than a specific firm. A firm may want to lobby for regulations that accrue benefits only to its own innovation while disadvantaging its competitors'. ${ }^{2}$ However, the rule making process of agencies is open and public, meaning that any political advantage that an individual firm tries to gain can likely be eroded away by counteractions from competitors (Capron \& Chatain 2008) (e.g., lawsuits).

Given these institutional features of public agencies (Choi, Jia \& Lu 2015, Grandy \& Hiatt 2020), when lobbying regulatory agencies, firms will have to provide information that suggests that the change will serve the industry overall rather than a firm's narrow interest. In other words, regulatory agencies will only be receptive of information and take regulatory action when they believe that the regulatory changes are consistent with the purpose of serving the industry. In this vein, prior literature has found that lobbying to federal agencies is more successful when a larger group of entities advocates for a particular change (e.g., Yackee \& Yackee 2006, McKay \& Yackee 2007). When many individual firms support a change, it can indicate to policymakers that the new regulation is likely to benefit the industry overall. For this reason, firms have been known to cooperate during lobbying efforts to effectively push

\footnotetext{
${ }^{1}$ Existing studies on lobbying do document narrowly-focused regulatory concessions gained from individual lobbying efforts, such as favorable decisions on a specific new drug (Barber IV \& Diestre 2019, Diestre et al. 2020) or tariffs against a directly competing foreign product (Kim 2017). However, there is little evidence to suggest that a single firm on its own can manipulate industry regulation when those regulatory changes will have direct consequences for other firms.
} 
for changes (e.g., Salisbury 1990, Hula 1999, Holyoke 2009). This is also evident in the SSO literature where competing firms often cooperate and are able to agree on a set of formal rules that can have an overall positive impact on the technologies of an industry (Rysman \& Simcoe 2008, Farrell \& Simcoe 2012, Simcoe 2012). Therefore, when firms of an industry seek changes from federal agencies, they will tend to pursue a set of regulations most firms and their technologies can benefit from.

\section{The Unintended Outcome of Lobbying}

\section{Knowledge leakage}

Firms are more likely to be successful in their technology policy lobbying efforts if they are able to convey the message that a particular set of regulatory changes will be helpful for many firms' innovations (McCaffrey 1982, Ungson et al. 1985, Denhardt \& Denhardt 2000, Hiatt \& Park 2013, Grandy \& Hiatt 2020). Therefore, firms need to identify a set of regulations that will support new technologies from a large number of firms across the industry. However, the firms are unlikely to know immediately what set of regulations can accomplish this. Firms will lack detailed knowledge about the innovations others are pursuing at a given point in time, meaning that it is unclear which technology policies would be helpful for others. Consequently, firms need to develop an understanding of others' new technologies and regulatory changes that could be supportive of these new technologies. Information about the technologies of others is needed to clarify what regulations could be successfully lobbied

for by the industry overall. Interactions among lobbyists representing different firms is a key process through which firms can share information to better understand each other's interests in the industry's technology policies (Carpenter, Esterling \& Lazer 2004, Fernandez \& Gould 1994). These interactions can help identify a set of regulatory changes that would benefit a large number of innovations across the industry (e.g., Laumann \& Knoke 1987). Therefore, in order to successfully bring about the intended benefit of lobbying, the industry collectively needs to undertake discussions about new technologies and potential policy changes. 
Although theses interactions among lobbyists are aimed at identifying mutually beneficial changes, because firms of an industry are competitors, firms are often seeking opportunities to gain advantage over their rivals even during the lobbying process (Drutman 2015, Holyoke 2009). Similarly, in SSOs, although firms interact with the goal of establishing technological standards for the industry, firms often act on their competitive nature by exploiting opportunities that arise during the process (Ranganathan et al. 2018, Jones et al. 2020). For example, when firms are required to disclose technological knowledge during the standard setting procedure, competitors seek to expropriate the new knowledge that is revealed (Toh \& Miller 2017). In this way, the formal steps of SSOs can provide opportunities for expropriation. Then for such competitive dynamics to manifest themselves during lobbying as it does in SSOs, the interactions involved in the lobbying process must also provide similar opportunities.

However, unlike in SSOs, lobbying does not formally require the disclosure of technological knowledge. Nevertheless, firms have expressed that mere verbal interactions with competitors are effective ways in which firms can gain knowledge about competitors' innovations (Levin, Klevorick, Nelson, Winter, Gilbert \& Griliches 1987, p806). In addition, the inadvertent leakage of knowledge to competitors during intraindustry interactions has been documented in a variety of other settings - during fundraising among startups in the medical device industry (Cox Pahnke et al. 2015), corporate investments in entrepreneurial ventures (Dushnitsky \& Shaver 2009), and mergers and acquisitions between advertising firms (Rogan 2014) -where disclosures to competitors are not formally required. Firms have also expressed that the leakage of knowledge during lobbying is a concern for them (de Figueiredo \& Tiller 2001, de Figueiredo \& Kim 2004, Jia 2018). Leakage occurs because in order to identify specific policies to pursue, lobbying requires sharing information about which direction of innovation the firm has had success with recently, the trajectory of technologies that the focal firm is currently pursuing, and future plans of technology development. Learning about a firm's experience and the outcomes with specific trajectories of technologies can be useful for competitors' technological strategy by helping competitors seize the same opportunities 
without repeating mistakes (Eggers 2012, Clough \& Piezunka 2020, Krieger 2021). Therefore, despite the lack of a formal mechanism that requires disclosure, lobbying can lead to the leakage of knowledge that is strategically valuable to competitors.

Overall, this suggests that many interactions needed for lobbying are intertwined with technological leakage. Put differently, if firms want to successfully bring about the intended regulatory changes, the interactions that involve knowledge leakage seem difficult to avoid. Interviews I conducted over two years with lobbyists and policy experts across many industriesincluding energy, medical device, telecommunication, technology, finance, transportation, and defense - confirmed the frequent occurrence of knowledge leakage to competitors during lobbying. For example, the following quote from a policy expert form the Silicon Valley explains why leakage may be inevitable during lobbying.

"Anything we relay to policymakers, we assume it will be leaked. So we are tightlipped about extremely sensitive information. However, based on the specific policies and issues that a competitor in the industry cares about during industry meetings or conversations with policymakers, you can learn about the technology that the competitor is interested in, especially if you are knowledgeable about the industry."

This policy expert states that because firms are generally aware that leakage happens during lobbying, inhouse lobbyists such as himself take action to try to minimize leakage where possible. However, crucially, he conveys that policy discussions with competitors often lead to an indirect disclosure about one's innovations. Nevertheless, these interactions are essential for firms' lobbying efforts. Overall, this suggests that despite preventative measures, knowledge leakage is still occurs for firms that lobby for their innovation.

Hypothesis 1. Firms that lobby for innovation will leak greater amounts of knowledge than firms that do not lobby for innovation.

However, not all types of lobbying may be equally leaky. Firms can choose to lobby through inhouse lobbyists they employ within the firm. Firms can also contract external 
lobbyists from professional lobbying firms (Jia 2014). Inhouse lobbyists are members of the firm who generally have detailed understandings about the policies directly relevant for the firm's activities. External lobbyists are often career politicians who have access to specific branches of the government or politicians (i Vidal, Draca \& Fons-Rosen 2012, Jia 2014). Although inhouse lobbyists as longterm employee of the firm may have a deeper knowledge about firms' activities, they often lack the political connections external lobbyists possess. In order to effectively change regulations, firms may need to share information with specific agencies or policymakers with whom the firm does not have existing relationships and is therefore difficult to reach (Baumgartner, Berry, Hojnacki, Leech \& Kimball 2009). To overcome such hurdles, firms can hire external lobbyists who have direct contacts. However, as illustrated below in the quote from an interview with an inhouse lobbyist, outsourcing of lobbying can be especially leaky.

"We have to occasionally share sensitive information with outside consultants in order to enlist their help..., and that comes with the risk that these political consultants may choose to reveal some of the sensitive information to their other clients depending on the circumstances."

The lobbyist states that employing outside lobbyists is especially prone to leakage. As external consultants employed by the firm when specific needs arise, external lobbyists' incentives are likely to be misaligned with those of the focal firm in a critical way (de Figueiredo \& Tiller 2001, de Figueiredo \& Kim 2004, Jia 2018). The focal firm and its inhouse lobbyists have the interest of changing regulations while minimizing the leakage of technological knowledge as stated explicitly in an earlier quote from the Silicon Valley inhouse lobbyist. Conversely, while the external lobbyist is also hired to help change the regulation, the consultant does not necessarily have an interest in preventing knowledge leakage. In fact, the inhouse lobbyist from the telecommunication industry implies that it is often in the interest of external lobbyists to act on their opportunistic nature and share sensitive information with competitors (Williamson 1985, 1996). Such behavior could help satisfy other clients of 
the external lobbyist or help expand the lobbyist's client base. Overall, the risk of knowledge leakage from external lobbying seems to be greater than internal lobbying.

Hypothesis 2. Increases in firm's external lobbying for innovation will lead to greater amounts of knowledge leakage than increases in inhouse lobbying for innovation.

When technological knowledge of the lobbying firms leaks, competitors can use the leaked knowledge to create innovations that are highly similar to the compromised innovation (e.g., Mansfield et al. 1981, Mansfield 1985, Lieberman \& Montgomery 1988). When the knowledge from innovations are expropriated in this way, compromised innovations lose value because the knowledge from the innovation is no longer able to serve as a solution to technological problems nor be a source of future technologies exclusively for the focal firm (Arrow 1962, Ahuja et al. 2013). Therefore, given that knowledge may be expropriated through imitation (Teece 1986, Barney 1991), leakage represents a risk for lobbying firms.

To sum, the lobbying process does not formally entail the provision of an opportunity for competitors to exploit. However, many lobbying interactions that can lead to knowledge leakage - such as discussions about technology and policy — are needed to successfully bring about regulatory changes in the industry. In this way, lobbying still presents opportunities for competitors to capitalize. In particular, competitors may take advantage by expropriating the leaked knowledge to create imitative technologies. Put differently, to accomplish the intended goal of reducing uncertainty associated with new technologies, lobbying firms will have to bear the risk of unintended knowledge leakage. Therefore, lobbying firms will experience greater knowledge leakage than non-lobbying firms (Hypothesis 1). In addition, due to opportunistic nature of external lobbyists, increases in outsourced lobbying is likely to result in greater knowledge leakage than increases in inhouse lobbying (Hypothesis 2). 


\section{Methods}

\section{Data}

The data used to test the hypotheses consists of three major parts: lobbying, regulation, and patent data. I obtained the lobbying variables from the lobbying report-level data available on LobbyView (Kim 2018). This includes all details from 1999 to 2020 that registered lobbyists are required to file on a quarterly basis. In essence, it contains all of the information on federal lobbying activities in the United States during this time period. With respect to the aims of the paper, the LobbyView data provides information on the client of the lobbyist (e.g., firms that engaged in lobbying) as well as the specific branches of the federal government that was targeted by the lobbying client (e.g., specific federal agencies). I focused on lobbying reports that had been assigned a GVKEY in the client field, which indicates that a U.S. public firm was behind the lobbying effort.

RegData includes textual data on all federal regulations in the Code of Federal Regulations ("CFR") from 1970 to 2020, a document published yearly by the federal government which lists federal regulations from all agencies and thus covers every industry (Al-Ubaydli \& McLaughlin 2017, McLaughlin \& Sherouse 2018, 2019, McLaughlin, Sherouse, Febrizio \& King 2020). Although the CFR is complete in its listing of federal regulations, the original document does not list the regulations according to which federal agency is behind the particular regulation. The CFR is organized according to a set of "titles" and subcomponents of titles called "parts." RegData matched each part within titles to federal agencies depending on how relevant that regulation is to the official purview of different federal agencies (Al-Ubaydli \& McLaughlin 2017, McLaughlin \& Sherouse 2018, 2019, McLaughlin et al. 2020). ${ }^{2}$ This results in a text-based dataset that tracks the regulation set by each federal agency over time. I

\footnotetext{
${ }^{2}$ The matching of parts of the CFR to federal agencies is not a one-to-one match, but a probabilistic match. In other words, a part of the CFR is often associated with multiple agencies at different weight levels based on the strength of relevance. This makes sense because the titles and parts often correspond to a specific industry, and an individual industry is likely to be influenced by the regulation of multiple federal agencies.
} 
crosswalked the federal agency information provided in RegData with the LobbyView data by matching hundreds of unprocessed agency names by hand. This allows me to observe how much lobbying was directed towards specific federal agencies and the change in regulations under the purview of those agencies over time. Furthermore, I hand-collected data from the Federal Register ("FR") API to identify agencies that made regulatory changes classified as "Science and Technology" in a given year according to the FR's classification system. This allows me to discern which firms' lobbying activities were directed at agencies making innovation-related regulatory changes in a given year.

With the lobbying and regulation data in hand, I now added patent data. I obtained data on U.S. patents from Kogan, Papanikolaou, Seru \& Stoffman (2017) and the United States Patent and Trademark Office's Patents View ("USPTO") database. Kogan et al. (2017) provides information on patents assigned to U.S. public firms, which allows me to identify the patents of firms that engaged in lobbying to federal agencies for their innovation during the sample period. The USPTO data includes the abstract text of each patent from 1976 to the present. I use the abstracts of patents to measure knowledge leakage, explained in further detail below in the Dependent Variable section.

This final dataset captures, for the firm assigned to each patent, the amount of lobbying directed at agencies making innovation-related regulatory changes during the year that the firm applied for the patent.

\section{Empirical Strategy}

There are four main empirical challenges - two regarding measurement and two regarding identification - for testing the effect of lobbying for innovation on knowledge leakage. 


\section{Measurement challenges}

With respect to measurement, both the (i) independent variable of lobbying for the specific purpose of innovation and the (ii) dependent variable of knowledge leakage have never been directly operationalized in prior studies.

(i) U.S. firms are required to report their lobbying activity to the federal government each quarter. However, the report does not detail the specific purpose of firms' lobbying (Kim 2018), making it difficult to distinguish lobbying undertaken for different objectives (e.g., trade, tax, innovation). I attempt to overcome this challenge by manually creating a unique dataset where I can observe lobbying directed at agencies making innovation-related policy changes as describe above in the previous Data section. The specific operationalization of the variable is described in greater detail below in the Independent Variables section.

(ii) Knowledge leakage is a concept that has been theorized widely in prior literature from transaction cost economics, resource based view of the firm, and strategic human capital (e.g., Williamson 1985, Barney 1991, Agarwal, Ganco \& Ziedonis 2009). However, it has been difficult to measure empirically, especially in the technology context, because existing institutions like the patent regime are designed in part to control unwanted knowledge expropriation. At the same time, prior literature suggests that the patents system does not do a perfect job of preventing instances of knowledge leakage in the form of imitative patenting by competitors (Mansfield et al. 1981, Mansfield 1985, Anton \& Yao 2004). Therefore, I devise a new machine learning-based measure for knowledge leakage in which I try to be

mindful about the objective of the patent system but also take advantage of its weaknesses. I measure knowledge leakage during the time period in which patents are arguably most vulnerable. This measure is described in detail below in the Dependent Variable section. 


\section{Identification challenges}

There are two fundamental identification challenges to testing the effect of lobbying for innovation on knowledge leakage: (iii) other sources of knowledge leakage and (iv) correlated drivers of lobbying.

(iii) Prior literature has identified many other potential sources of knowledge leakage, such as SSOs (Rysman \& Simcoe 2008, Simcoe 2012, Toh \& Miller 2017), strategic alliances (Gulati, Nohria \& Zaheer 2000, Vasudeva, Zaheer \& Hernandez 2013, Funk 2014), employee mobility (Agarwal et al. 2009, Ganco 2013, Ganco, Ziedonis \& Agarwal 2015), and geographic clusters (Jaffe, Trajtenberg \& Henderson 1993, Alcacer \& Chung 2007, Kim, Shaver \& Funk 2022), which may be correlated to lobbying for innovation. To overcome this challenge, I directly control for these factors using a collection of variables described in the Control Variables section.

(iv) Firms that engage in lobbying for innovation, compared to those that do not, or firms that lobby for innovation more intensely than those who lobby less intensely, may differ in ways that are related to the leakage of knowledge. In particular, firms keen on lobbying for innovation may be from different industries, have particular firm attributes, or tend to generate specific types of innovations - all of which may be related to the likelihood of imitative patenting by competitors. In an attempt to rule out these specific endogeneity concerns, I compute additional variables explained in the Control Variables section.

Finally, further measurement and identification challenges suggestive of alternative explanations are discussed and addressed in the Supplementary Analysis section.

\section{Dependent Variable}

Knowledge leakage To measure the extent to which technological knowledge used in an innovation is leaked, I utilize a novel deep learning methodology, Doc2Vec. ${ }^{3}$ I employ this

\footnotetext{
${ }^{3}$ I conducted most of the computations involved in the Doc2Vec procedure using the Gensim package on Python (Rehurek \& Sojka 2010).
} 
machine learning approach on the abstracts of each patent to count how many alter patents of other firms expropriate a large portion of the technological knowledge embodied in the text of a focal patent. Figure 1 provides a visual scheme of the measure.

According to prior literature, the knowledge used to create innovations resides in the components of the innovation (Fleming 2001, Fleming \& Sorenson 2004). In other words, ff two patents are based on a similar set of technological knowledge, they will use a comparable collection of technological components. Prior studies have used abstracts of patents to understand the technological components of innovations (e.g., Kaplan \& Vakili 2015, Arts, Cassiman \& Gomez 2018). Therefore, I measure the similarity of abstract text to infer the commonality in the technological components of two patents. In particular, I focus only on the nouns found in the abstracts because technological components are physical objects or conceptual ideas, which are most likely to be represented by nouns (Arthur 2021). ${ }^{4}$ Based on this approach, I should be able to detect technological knowledge leakage across firms. The intuition is that when a competitor's new patent uses technological components highly similar to an earlier patent from the focal firm after both firms were involved in lobbying for technology policy, the similarity in their patents may be due to the leakage of technological knowledge from the focal firm to the competitor during their lobbying interactions.

Using Doc2Vec, I am able to measure the meaning of each noun based on the nouns that appear close to the particular word. Inferring the meaning of a word from its textual context is grounded in an established theoretical perspective in linguistics (Miller \& Charles 1991). Utilizing this approach, I capture the meaning of each noun - or the technological knowledge embodied in each technological component - as it appears in the abstracts of patents. I accomplish this without imposing any arbitrary assumptions about the nature of the original text, which is often required for other text analysis (e.g., Latent Dirichlet Allocation). This represent a significant advantage of Doc2 Vec in assessing the similarity across a large number of technical documents like patents since it may be hard to discern even basic characteristics

\footnotetext{
${ }^{4}$ I provide more information on the preprocessing steps as well as further details in Appendix A.
} 
of the documents - such as the number of expected categories - without expert knowledge of many specialized fields.

After obtaining the vectors of technological knowledge embodied in each patent, I now need to identify the set of potential alter patents which may have expropriated knowledge from the focal patent. First, I only consider, as potential alters, patents that are applied for by other firms within the same CPC subclass. This narrows the set of potential alter patents to those from competitors that are interested in the same technology policies, which means that lobbying interactions present an opportunity for knowledge leakage to occur. Second, I only consider patents as potential alters if they were applied for after at least a month of the application date of the focal patent. The reason for focusing only on subsequent patents in general is to make an inference about which patent the leaked knowledge originated from between the two patents that use similar technological knowledge. The competitor who uses a set of technological knowledge found in an earlier patent is likely to be the one that is expropriating another firm's knowledge. I only consider alter patents from at least a month after the application date of the originating patent because it will likely take the competitors some time to pick up knowledge from lobbying and expropriate the knowledge by filing for new patent applications. For example, two highly similar patents that are filed almost concurrently may represent simultaneous discoveries (Bikard 2020) rather than knowledge leakage during lobbying. Finally, I only consider patents as potential alters if they were applied for within 18 months of the focal patent's application date. This is because starting in November 2000, following the passage of the American Inventors Protection Act (AIPA), patent applications were by default required to be disclosed 18 months after the filing date. Therefore, for highly similar alter patents filed after more than 18 months of the focal patent, I am not able to rule out the potential for the similarity to be arising from the public disclosure of the patent application. ${ }^{5}$

\footnotetext{
${ }^{5}$ Although the USPTO by default discloses patent applications 18 months after the filing date, some patents are granted before 18 months and firms can opt out of the disclosure policy. In order to deal with these differences, I drop patents that are granted within 18 months of filing date and drop patents with "Kind Code" value "B1" according to the USPTO database.
} 
Therefore, the window of opportunity to observe knowledge leakage is the 17-month period, starting after a month of the focal patent's filing date, but before the the application is disclosed 18-months from the filing date. For a focal patent, the start of this time period is approximately when its technological knowledge begins to be available for leakage and the remaining time until the end of this period is when the focal patent is most vulnerable to expropriation. Knowledge leakage could still occur outside of this narrow window. However, to be conservative in the measurement approach, I focus on potential alter patents applied for during this time period where the similarity found between two patents is most likely to correspond to the leakage and expropriation that stems from lobbying.

In order to measure knowledge leakage from the focal patent to this set of alter patents, I compute the pairwise Cosine similarity. Thereafter, I calculate the $95^{\text {th }}$ percentile pairwise Cosine similarity for the set of patents in the same CPC subclass and application year. This threshold represents a high level of technological knowledge similarity between a firm's patents and those applied for by competitors. Finally, for each patent, I count the number of alter patents that are higher in similarity than the threshold. This measure captures the number of subsequent patents that are extremely similar to the focal patent and are applied for by other competitors in the industry with whom the firm potentially lobbies. Therefore, this measure should capture the number of patents that are likely expropriating leaked knowledge from the focal patent. Appendix A provides additional details about this measure.

\section{Independent Variables}

Lobbying for innovation The report-level data on LobbyView includes information on the client of the lobbyist (e.g., the firm that employees the lobbyist). LobbyView has matched the client information, where applicable, to a GVKEY (Kim 2018). I focus on the set of lobby reports that include a GVKEY, which should cover all of the lobbying that is done by public firms. In addition, the lobbying reports provide information on which branch of the government was lobbied during the year. I focus only on lobbying that targeted 
federal agencies (e.g., Barber IV \& Diestre 2019, Ridge, Ingram \& Hill 2017). This is because the federal agencies are the ones that are responsible for instituting changes in the federal regulations that are most directly relevant for firm activities in an industry (e.g., Grandy \& Hiatt 2020, Navis \& Glynn 2010). I also need to identify lobbying efforts specifically about new technologies of the industry. Using hand collected data from the Federal Register ("FR"), I identify lobbying directed at agencies that made regulatory changes classified as "Science and Technology."

In order to estimate the extensive margins associated with lobbying, I calculate a dummy variable Lobbying for innovation (dummy), which takes on a value of 1 if a firm lobbies an agency that makes an innovation-related regulatory change according to the FR during the year in which the firm applied for the focal patent. Similarly, to estimate the intensive margins associated with lobbying, I compute Lobbying for innovation (amount), which is natural log of 1 added to the dollar amount of lobbying directed at regulatory change related to innovations according to the FR during the application year of the focal patent. I further distinguish lobbying that is outsourced to external consultants by the focal firm, Lobbying for innovation (amount outsourced), and lobbying carried out inhouse by the firm itself, Lobbying for innovation (amount inhouse), based on the information provided by LobbyView.

\section{Control Variables}

I first explain how I try to alleviate the identification challenge of controlling for other known factors which could contribute to the leakage of knowledge. Subsequently, I explain how I attempt to address the identification problem of confounding factors that could contribute to the firm's decision to lobby for innovations as well as knowledge leakage.

Prior research has already documented other ways in which technological knowledge could permeate across firms. First, SSOs are a venue in which firms choose to strategically share specific technological knowledge (Rysman \& Simcoe 2008, Simcoe 2012, Toh \& Miller 2017). Firms that are active in SSOs may also be more keen on lobbying for innovation. Therefore, 
in order to deal with this concern, I use data on standard essential patents (Bekkers, Catalini, Martinelli \& Simcoe 2012). I drop patents that are indicated to be involved in SSOs according to this dataset. Because this data only contains information up to 2015, I am not able to discern which patents may have been disclosed in SSOs after 2015. Therefore, I restrict my sample to patents applied for prior to 2015. Second, firms form strategic alliances, often with the explicit intent to share technological knowledge (Gulati et al. 2000, Vasudeva et al. 2013, Funk \& Hirschman 2014). Firms that are actively engaged with one aspect of the external environment, such as the political landscape through lobbying, may also be inclined to form strategic alliances with other firms. In order to address this concern, I collected data on strategic alliances from SDC platinum. I include the control, Strategic alliance, or the number of alliances of each firm that started within five years of the application year of the patent. Third, the movement of employees across firms is another known channel through which knowledge leakage could occur (Agarwal et al. 2009, Ganco 2013, Ganco et al. 2015). We also know that U.S. states vary in their stringency of noncompete agreements to try to address employee mobility as a source of knowledge leakage among competitors (Marx et al. 2009). Therefore, to proxy for the movement of employees who could be leaking knowledge, I collected data on the location of the headquarter of firms using Compustat and Gao, Leung \& Qiu (2021). Thereafter, I used data from Ewens \& Marx (2018) to compute Noncompete change, which is aimed at controlling for changes in noncompete agreements in the state that the firm's headquarter is located. Fourth, industry clusters are another well-documented source of knowledge transfer and leakage (Jaffe et al. 1993, Alcacer \& Chung 2007, Kim et al. 2022). Firms that are located in dynamic clusters may also have a higher interest in lobbying for their innovation. To alleviate geographic clusters as a potential confounding variable, using the headquarter location information, I compute Patents from same state, or the number of patents in the same $\mathrm{CPC}$ subclass and application year as the focal patent originating from a public U.S. firm headquartered in the same state. 
In addition, firms keen on lobbying for innovation may be different in terms of their industry, firm, and innovation characteristics in ways that are related to knowledge leakage. Prior literature has suggested that firms in less competitive industries are more likely to lobby (Stigler 1971). Perhaps firms in these entrenched, stale industries have a tendency to produce similar innovations regardless of lobbying. Alternatively, recent studies suggest that lobbying can be a source of competitive advantage (Kim 2017), implying that in fiercely competitive industries where imitation is more likely to occur, firms may engage in lobbying to eke out political advantages against rivals. Put together, the level of competition firms face in their industry is likely an important control. Therefore, I include Firm competition, a proxy for the level of competition that a firm faces given their industry's product market structure (Hoberg \& Phillips 2016). In addition, the lobbying literature has shown that firms that are larger and more resourceful tend to engage in lobbying (Baumgartner et al. 2009, de Figueiredo \& Richter 2014, Drutman 2015). More resourceful firms may be ones that generate better new technologies that are worth imitating (Cohen \& Levin 1989, Cassiman \& Veugelers 2006), regardless of the firm's decision to lobby. Thus, in order to control for the resources of the firm which may impact the quality of innovation, I include Revenue and Firm patent count during the focal patent's application year as controls. Finally, firms that create a specific type of innovation may be more inclined to lobby. I have argued above that the reason why firms lobby is to reduce uncertainty of their new technologies, implying that firms that produce patents higher in novelty may feel a stronger need to lobby. Patents higher in novelty, by departing from the existing technological trajectories (Dosi 1982, Funk \& Owen-Smith 2017, Park, Leahey \& Funk 2022), may tend to use more new components - or nouns in their abstracts - which are subsequently adopted by future patents that are not necessarily expropriating any knowledge from prior patents but simply using new components introduced by the highly novel patents. In other words, novelty of patents may be correlated with firms' lobbying decisions and mechanically related to the measure of knowledge leakage. 
In order to address this concern, I include the Patent novelty, or CD index within five years of grant year (Funk \& Owen-Smith 2017), as a control variable.

Finally, I also include Subclass patent impact, which is the average number of forward citations within five years of patents applied for in the same application year and CPC subclass, to proxy for how important and therefore strategically valuable it may be to expropriate knowledge from the focal patent's technology subclass. Furthermore, I also include Patent leakage alter ratio, which is the number of patents that are applied for in the same CPC subclass during the 17-month window where I observe Knowledge leakage divided by the number of patents that are applied for lobbying firms.

\section{Estimation Approach}

The sample consists of patents that were applied for by public U.S. firms between 2001 and 2015. I estimate the association between the lobbying that is conducted by the firm assigned to each patent during the patent's application year and the number of imitative patents from competitors. Since the dependent variable is a count of patents, I employ a fixed

effects Poisson approach to estimate the model (Hausman, Hall \& Griliches 1984, Azoulay, Graff Zivin \& Wang 2010, Furman \& Teodoridis 2020). The estimating equation takes the following form:

$$
\text { Knowledge leakage }_{i}=\exp \left(\beta_{0}+\beta_{1} \text { Lobbying }_{j t}+\beta_{2} \text { Controls }+\delta_{j}+\gamma_{t}+\theta_{k}+\epsilon_{i j k t}\right)
$$

In Equation 1, $i$ represents the focal patent, $j$ corresponds to the firm that is assigned to the focal patent, $t$ is the application year of the focal patent, $\delta_{j}$ represents the firm fixed effects, $\gamma_{t}$ corresponds to the application year fixed effects, and $\theta_{k}$ is the CPC subclass fixed effects. 


\section{Results}

Table 1 provides the summary statistics of the key variables. The average value of Knowledge leakage is 22 . In other words, each patent in the sample is associated with 22 imitative patents from competitors, which is not surprising given that prior literature has documented patents are often ineffective in preventing expropriation (Mansfield et al. 1981, Mansfield 1985, Cohen \& Levin 1989, Hall \& Ziedonis 2001, Anton \& Yao 2004). Among lobbying firms in the sample, each patent is associated with about $\$ 420,000$ of total lobbying, $\$ 90,000$ of outsourced lobbying, and $\$ 330,000$ of inhouse lobbying for innovation during the patent's application year.

\section{Main Results}

Table 2 provides the results for testing Hypothesis 1, where I predicted that knowledge leakage will be greater for lobbying firms than non-lobbying firms. Model 3 is the preferred model that includes all controls and fixed effects. ${ }^{6}$ The coefficient for Lobbying for innovation (dummy) is positive and significant $(\beta=0.1520, p<0.001)$. The magnitude of the coefficient form Model 3 suggests that the patents of lobbying firms are associated with 4 more imitative patents than the patents of non-lobbying firms. Put differently, when firms decided to engage in lobbying for innovations, they can expect the number of imitative patents from competitors to increase by $21 \%$. To verify that the unbalanced distribution of lobbying and non-lobbying firms are not driving the positive association observed in the full sample models (Iacus, King \& Porro 2012), I conduct coarsened exact matching. ${ }^{7}$ I find consistent results, which are reported in Model 4. Overall, these patterns support Hypothesis 1.

\footnotetext{
${ }^{6}$ I exclude firm-level fixed effects when estimating the extensive margins of lobbying because firms rarely stop lobbying once they start (Drutman 2015). To this point, I observe that only $3 \%$ of the sample has any within-firm variation in Lobbying for innovation (dummy).

${ }^{7}$ I use the 'cem' package in Stata 16 (Blackwell, Iacus, King \& Porro 2009) to carefully match patents on patent application year, patent CPC subclass, assignee firm NAICS code, revenue, firm patent output in application year, and competition. The procedure produces a sample of treated and untreated patents which are statistically comparable across key potential confounding variables identified in the Control Variables section.
} 
Table 3 provides the results for testing Hypothesis 2, where I predicted that the knowledge leakage from outsourced lobbying will be greater than the leakage from inhouse lobbying. I find that the coefficients for the total (Model 1) and inhouse (Model 3) lobbying amounts are not statistically different from zero. However, I find that the leakage associated with outsourced lobbying (Model 2) is positive and significant $(\beta=0.0252, p<0.01)$. The magnitude of the coefficient in Model 2 suggests that increasing outsourced lobbying from $\$ 0$ to $\$ 100,000$ is associated with 7 more imitative patents, which is $30 \%$ of the mean. In

Figure 2, I plot the $95^{\text {th }}$ percentile confidence intervals of the two coefficients from Models 2 and 3 to directly compare their magnitudes. The lower bound of the estimate from Model 2 is greater than the upper bound of the estimate from Model 3, suggesting that the coefficient of outsourced lobbying is statistically greater than that of inhouse lobbying. These patterns are consistent with Hypothesis 2.

\section{Supplementary Analysis}

In the main estimation approach, I tried to carefully address empirical challenges by devising new measures that directly operationalized the independent and dependent variables (see points (i) and (ii) in the Empirical Strategy section) and by controlling for known factors that could be related to knowledge leakage as well as firms' lobbying decisions (see points (iii) and (iv) in the Empirical Strategy section). As a result, I have found strong empirical support for my theory linking lobbying and knowledge leakage. However, there still remain two potential alternative explanations which could account for the statistical patterns I have presented above. I now rule out these alternative explanations through empirical explorations, insights from field interviews, and findings from prior literature to show that the main results are robust to additional measurement and identification concerns. 


\section{Is Knowledge leakage a strategic outcome? (Measurement error)}

Empirically, I have shown a strong associative relationship between lobbying and Knowledge leakage, using a new measure which is based on imitative patenting. Theoretically, I proposed that knowledge leakage is an unintentional consequence that firms face during lobbying because firms have to disclose information about their own innovation activity. Put differently, I have implied that Knowledge leakage is a form of technological cost to lobbying for innovation. However, given that firms are aware that knowledge leakage is a risk inherent in lobbying (de Figueiredo \& Tiller 2001, Jia 2018), it is possible that firms are able to strategize the spillage of technological knowledge during lobbying, disclosing information in ways that benefit their new technologies. In particular, firms could be strategic with the objective of making their patents more widely-known throughout the industry and therefore impactful. If firms were strategizing the leakage that occurs during lobbying, the text similarity measure of Knowledge leakage could be capturing the increase in the usage of technological knowledge of the focal patent in subsequent patents like a forward citation measure, as opposed to documenting a potential negative consequence for the focal patent. This alternative explanation would suggest that there is a measurement error and would undermine the validity of my theoretical argument about the nature of leakage.

However, insights from an empirical exercise, field interviews, and prior literature suggest that this alternative explanation is unlikely. If Knowledge leakage were capturing a positive consequence arising from lobbying, as opposed to a negative one as I theorized, we should expect to see a positive association between the measure and the value of the patent. In order to assess the nature of knowledge leakage captured by the measure, I explore its relationship with an existing measure of patent financial value (Kogan et al. 2017), which is based on the abnormal stock market prices of the assignee firm when a particular patent is granted to the firm. The results are presented in Table 4. In Model 3, in addition to the fixed effects, I control for factors likely closely associated with Financial value such as the number of forward citations the patent receives within five years of granting to account for the quality 
of the focal patent, the average number of citations the assignee firm's patents from the same application year receive within five years to account for the changing innovative capability of the firm, as well as the average number of citations patents in the same CPC subclass and application year receive within five years to account for the changing impact of the specific technology subcategory. Across the models, I find a robust negative association between Knowledge leakage and Financial value. Specifically in Model 3, the estimate suggests that when the number of imitative patents increases from 0 to 7 (the magnitude of increase in imitative patents when outsourced lobbying increases by $\$ 100,000$ according to Table 3 Model 2 ), the value of the patent decreases by about $\$ 49,000$, which is $0.45 \%$ of the average financial value of patents in the sample. ${ }^{8}$ It is noteworthy that the negative association between Knowledge leakage and Financial value exists over and beyond the known antecedents of patent value such as the impact of the patent itself, innovation capabilities of the firm, and the trajectory of the patents technology subclass (Teece 1986, Kogan et al. 2017, Anderson \& Tushman 1990). This provides strong evidence against the alternative explanation that hinged on a measurement error where Knowledge leakage was capturing some positive patent outcome rather than a negative one as I proposed.

In addition, prior literature and interviews suggest that lobbyists are unlikely to be employed by firms to strategically reveal technological information (Drutman 2015, Baumgartner et al. 2009). Although lobbyists are experts about the political landscape as it relates to firms' activities, they lack specialized knowledge about specific patents and the underlying technologies of those patents. Furthermore, prior literature on innovation has documented the explicit ways in which firms engage in strategic knowledge sharing, such as SSOs (Rysman \& Simcoe 2008, Simcoe 2012, Toh \& Miller 2017) and alliances (Gulati et al. 2000, Vasudeva et al. 2013, Funk 2014), both of which are empirically accounted for in the main models. Given the lack of capabilities to transfer detailed technological knowledge and other proven

\footnotetext{
${ }^{8}$ Considering that the average firm in the sample applies for about 370 patents each year, the estimates here would suggest that firms could incur costs of up to $\$ 18,130,000$ from a $\$ 100,000$ increase in outsourced lobbying.
} 
ways in which firms can do so effectively, it seems unlikely that firms would use lobbyists as conduits of strategic knowledge exchange with other firms.

Overall, empirical, contextual, and theoretical insights suggest that Knowledge leakage does capture an unintentional technological outcome of lobbying for innovation. This alleviates concerns of measurement error and provides further support for the main argument about lobbying and knowledge leakage.

\section{Is patenting driving lobbying? (Reverse causality)}

I have interpreted the strong association between lobbying and leakage as firms' lobbying activity driving the leakage of technological knowledge. However, there is potential for what is captured by Knowledge leakage to inform lobbying decisions. To this point, prior literature has suggested that firms try to undertake lobbying strategically (Jia \& Mayer 2016, Ahuja et al. 2018, Oberholzer-Gee \& Yao 2018). More specifically, firms may choose to lobby based on the extent to which the patents they are applying for at the time include technological knowledge already widely known throughout the industry. In other words, Knowledge leakage could be capturing the extent to which knowledge about a focal patent has already diffused to competitors. Given that firms are aware of leakage during lobbying, they may only choose to lobby when they have less knowledge to leak in the patents under application. This alternative explanation would be consistent with the positive association between lobbying and leakage shown above, but would challenge the direction of causality in my theoretical arguments by raising concerns of reverse causality.

I now demonstrate why this alternative explanation is unlikely based on empirical evidence, field insights, and prior literature. If firms coordinate their lobbying decisions alongside patent applications as the alternative explanation entails, I should observe lobbying activity of firms to be related to some patent characteristics. For example, perhaps firms are more likely to significantly reduce their lobbying activity when applying for novel patents because these patents are more likely to contain knowledge that is new to competitors. Additionally, 
firms may be wary of lobbying when applying for patents with high impact or value. Put together, under the alternative explanation, I would expect to find a substantial amount of variance in lobbying activity explained by at least some of the following patent characteristics: Patent novelty (Funk \& Hirschman 2014) (see Control Variables), Patent impact (forward citations received within five years of grant year), or Financial value (Kogan et al. 2017). Table 5 presents the results of a Shapley-Owen decomposition analysis (Grömping 2007, Shorrocks et al. 2013, Kumar, Liu \& Zaheer 2022) using the 'shapleyx' command in Stata 16. This analysis estimates the relative contribution of patent characteristics, as well as revenue and firm and year fixed effects, in explaining the variation in lobbying. Across all three types of firm lobbying, I find that the three patent characteristics together explain less than $2 \%$ of the variation. In contrast, firm fixed effects explain a large portion of lobbying activity, which is expected given that firms have difficulty monitoring the efficacy of lobbying and therefore tend to replicate prior lobbying efforts (Baumgartner et al. 2009, Drutman 2015). Additionally, I note that Revenue also accounts for a substantial portion of firms' lobbying, consistent with existing findings (de Figueiredo \& Richter 2014). Overall, these patterns suggest that firms do not closely coordinate their lobbying and patenting activity, implying that it is unlikely for Knowledge leakage to drive firms' lobbying decisions.

Furthermore, prior literature on lobbying suggests that lobbyists are primarily concerned with fulfilling their role of changing regulations in specific ways (Baumgartner et al. 2009, Drutman 2015). Interviewed lobbyists explained that this entails understanding the political landscape of relevant policies, identifying stakeholders behind those policies, and crafting the framing of information to those stakeholders so that regulations change in the ways that firms desire. Notably, in the strategizing of lobbying, there does not seem to be much consideration for the status of specific patent applications as the reverse causality story would suggest. To this point, field interviews indicate that lobbyists rarely, if ever, engage in any sort of communication with patent lawyers; similarly, patent lawyers I interviewed stated they had never coordinated patent applications with lobbyists. To sum, given that the strategic 
decisions about lobbying are focused on effectively changing regulations, it seems unlikely for the content of patent applications to be driving lobbying decisions. Therefore, reverse causality does not seem to be a plausible alternative explanation for the empirical results, providing further support for the proposed theory.

\section{Discussion}

Although prior literature suggests that firms do engage in lobbying to benefit their innovations (e.g., Barber IV \& Diestre 2019, Diestre et al. 2020), many aspects of lobbying and innovation remained unexplored. This paper is the first to document an unintentional outcome of lobbying. Based on field interviews, prior literature, and a novel dataset, I develop and test a theory on how lobbying is associated with knowledge leakage. I also explore underlying mechanisms by empirically showing that external lobbyists, who have little incentive to be discrete in their lobbying efforts, are linked to greater knowledge leakage. Finally, using additional empirical exercises, insights from interviews, and evidence from literature, I demonstrate that the positive relationship between lobbying and leakage are robust to additional measurement and identification issues.

Overall, this paper illuminates a link between a political strategy and innovation activity by identifying an inherent tradeoff to lobbying for innovation. The potential benefit to lobbying is that firms could appropriate additional value from their technologies by strategically shaping regulation. However, firms also face a potential cost since they must disclose information about their innovation activity, which could lead to imitation by competitors. Although the appropriation and disclosure tradeoff has been identified in prior innovation literaturesuch as in patenting (Anton \& Yao 2004), SSOs (Toh \& Miller 2017), and investment relationships (Katila, Rosenberger \& Eisenhardt 2008) - this paper is the first to identify the strategic dilemma in the political arena. This politically technological conundrum inherent to lobbying for innovation represents a fundamental building block which provides a nuanced 
understanding of "integrated strategy" between politics and innovation (Jia \& Mayer 2016, Ahuja et al. 2018, Oberholzer-Gee \& Yao 2018).

When evaluating the results shown here, some limitations should be kept in mind. First, I am unable to observe the heterogeneity in lobbying that might exist other than what is recorded in the lobbying reports. For example, the effectiveness of lobbying may differ depending on the experience of the lobbyist or the importance of the policymaker who was targeted by the lobbyist (i Vidal et al. 2012). Furthermore, some lobbying activities may be strategically concealed (Jia, Markus \& Werner 2021). These details are not reported in a systematic source available to the public. However, they may play a significant role in the efficacy of lobbying. In other words, my measure of lobbying is likely to be coarse in some ways. Nonetheless, the data utilized in this study is the most exhaustive source of lobbying publicly available today. Second, I rely heavily on patent data. Although patent data have been used widely for innovation studies in the past (e.g., Fleming 2001, Funk \& Hirschman 2017), they are not a perfect measure of innovation. Many innovations may not be patented (Levin et al. 1987). I am unable to take those innovations into account.

Notwithstanding these limitations, this study makes contributions to both the innovation and nonmarket literature in interconnected ways. Although innovation is a widely studied topic across many fields, to my knowledge no existing study has directly explored the relationship between corporate political activity and innovation. This marks a significant contribution as I show that institutional changes that are purposefully instigated by firms can have consequences for new technologies - in direct contrast to other existing innovation studies that have mostly focused on exogenous institutional changes (e.g., Arora et al. 2021, Marx et al. 2009, Balsmeier et al. 2017). Given the increasing importance that firms are placing on lobbying (Drutman 2015), there is a substantive need for innovation scholars to understand what kind of relationship exists between lobbying and innovation. This paper represents one of the first steps in that direction. Furthermore, it adds to the existing literature that has explored factors external to the firm which can impact innovation such as technological 
trajectories (Anderson \& Tushman 1990), analysts (Benner 2010), institutional environments (Vasudeva et al. 2013), and networks (Kumar \& Zaheer 2019, Funk 2014).

In related ways, the paper also contributes to the nonmarket literature. Most importantly, it raises the significance of nonmarket literature overall by showing that nonmarket activities of firms can directly impact strategically important processes of innovation. Furthermore, it sheds light on unexplored aspects of lobbying. Although industry and firm lobbying have been a focus in management research (e.g., Barber IV \& Diestre 2019, Diestre et al. 2020, Ridge et al. 2017), prior literature has overlooked specific lobbying outcomes directly linked to technologies like knowledge leakage.

Of the many different ways in which future scholars can build on the framework developed in this paper, three stand out as especially promising. First, further efforts to closely understand the consequences of knowledge leakage would be helpful. I have shown empirically that leakage can impact the value of patents. However, interviews with lobbyists, policy experts, and agency employees suggest that this intriguing phenomenon is a widespread occurrence, whose impact is likely complex and extends beyond the financial value of the focal patent. For example, understanding which specific competitors learn about the lobbying firm based on the network among lobbyists and policymakers could be interesting. Assessing how lobbying and leakage within the industry impact the diversity of new technologies firms create seems promising. Second, exploring other unintended consequences of lobbying will also be interesting. For example, interviews revealed that small startups gain a significant amount of valuable information from joining trade associations and participating in industry lobbying. Therefore, probing the potential for "learning-by-lobbying" mechanism could further advance the field's understanding about other non-technological externalities of lobbying that may exist. Finally, examining the different types of regulatory change that firms seek through lobbying would be important. Prior literature suggests that there are many dimensions of regulations which can influence new technologies (e.g., Rogge \& Reichardt 2016, Geels et al. 2021, 2017). Future research that explores which specific types of change firms lobby for 
depending on the characteristics of their own innovations, level of technological competition in the industry, or the current conditions of the regulatory environment will represent a significant contribution to the Politics of Innovation.

Finally, this paper also provides strategic insights for firms seeking to reduce the leakage of knowledge that occurs during lobbying. I find that external lobbying, which is necessary at times to access specific individuals or offices within the government, is especially leaky. Firms are also aware of the heightened risk inherent to external lobbying. Therefore, one possibility could be to reduce external lobbying. However, firms require the service of external lobbyists in certain situations to change regulation. Thus, even reducing external lobbying is likely not a viable solution. A different strategy is internalization. Currently, most firms seem reluctant to internalize external lobbyists because the career politicians will demand high salaries given their specialized expertise. At the same time, although firms are aware of the leakage that can occur with outside lobbyists, they do not seem to be assessing the magnitude of the cost associated with the leakage. Firms mostly view leakage as an unavoidable cost. Carefully evaluating the financial loss from leakage requires close coordination between the departments of lobbyists, engineers, and patent lawyers, which is absent inside most firms. However, the empirical results here suggest that the financial loss from knowledge leakage can be as great as the total amount some firms expend on external lobbying. Therefore, for firms that rely on the competitiveness of their new technologies, strategically internalizing some of the external lobbying based on a coordinated cost analysis may improve performance. 


\section{References}

Agarwal, R., Ganco, M. \& Ziedonis, R. H. (2009), 'Reputations for toughness in patent enforcement: Implications for knowledge spillovers via inventor mobility', Strategic Management Journal 30(13), 13491374.

Ahuja, G., Capron, L., Lenox, M. \& Yao, D. A. (2018), 'Strategy and the institutional envelope', Strategy Science $\mathbf{3}(2)$, ii-x.

Ahuja, G., Lampert, C. M. \& Novelli, E. (2013), 'The second face of appropriability: Generative appropriability and its determinants', Academy of Management Review 38(2), 248-269.

Al-Ubaydli, O. \& McLaughlin, P. A. (2017), 'Regdata: A numerical database on industry-specific regulations for all united states industries and federal regulations, 1997-2012', Regulation \& Governance 11(1), 109-123.

Alcacer, J. \& Chung, W. (2007), 'Location strategies and knowledge spillovers', Management Science 53(5), 760-776.

Anderson, P. \& Tushman, M. L. (1990), 'Technological discontinuities and dominant designs: A cyclical model of technological change', Administrative Science Quarterly pp. 604-633.

Andrade, F. F. N., Figueiredo, F., Silva, D. \& Morais, F. (2020), Measuring disruption in song similarity networks, in 'Proc. of the 21st Int. Society for Music Information Retrieval Conf'.

Anton, J. J. \& Yao, D. A. (2004), 'Little patents and big secrets: managing intellectual property', RAND Journal of Economics pp. 1-22.

Aplin, J. C. \& Hegarty, W. H. (1980), 'Political influence: Strategies employed by organizations to impact legislation in business and economic matters', Academy of Management Journal 23(3), 438-450.

Arora, A., Belenzon, S. \& Sheer, L. (2021), 'Knowledge spillovers and corporate investment in scientific research', American Economic Review 111(3), 871-98.

Arrow, K. (1962), Economic welfare and the allocation of resources for invention, in 'The rate and direction of inventive activity: Economic and social factors', Princeton University Press, pp. 609-626.

Arthur, W. B. (2021), 'Economics in nouns and verbs', arXiv preprint arXiv:2104.01868 .

Arts, S., Cassiman, B. \& Gomez, J. C. (2018), 'Text matching to measure patent similarity', Strategic Management Journal 39(1), 62-84.

Azoulay, P., Fons-Rosen, C. \& Graff Zivin, J. S. (2019), 'Does science advance one funeral at a time?', American Economic Review 109(8), 2889-2920.

Azoulay, P., Graff Zivin, J. S. \& Wang, J. (2010), 'Superstar extinction', The Quarterly Journal of Economics 125(2), 549-589.

Balsmeier, B., Fleming, L. \& Manso, G. (2017), 'Independent boards and innovation', Journal of Financial Economics 123(3), 536-557.

Barber IV, B. \& Diestre, L. (2019), 'Pushing for speed or scope? pharmaceutical lobbying and food and drug administration drug review', Strategic Management Journal 40(8), 1194-1218.

Barney, J. (1991), 'Firm resources and sustained competitive advantage', Journal of Management 17(1), 99120.

Baroni, M., Dinu, G. \& Kruszewski, G. (2014), Don't count, predict! a systematic comparison of contextcounting vs. context-predicting semantic vectors, in 'Proceedings of the 52nd Annual Meeting of the Association for Computational Linguistics (Volume 1: Long Papers)', pp. 238-247. 
Baumgartner, F. R., Berry, J. M., Hojnacki, M., Leech, B. L. \& Kimball, D. C. (2009), Lobbying and policy change: Who wins, who loses, and why, University of Chicago Press.

Baysinger, B. D. (1984), 'Domain maintenance as an objective of business political activity: An expanded typology', Academy of Management Review 9(2), 248-258.

Bekkers, R., Catalini, C., Martinelli, A. \& Simcoe, T. (2012), Intellectual property disclosure in standards development, in 'Conference Proceedings of the NBER conference on Standards, Patents \& Innovation', Vol. 10.

Benner, M. J. (2010), 'Securities analysts and incumbent response to radical technological change: Evidence from digital photography and internet telephony', Organization Science 21(1), 42-62.

Bernstein, M. H. (1955), Regulating business by independent commission, Princeton University Press.

Bikard, M. (2020), 'Idea twins: Simultaneous discoveries as a research tool', Strategic Management Journal 41(8), 1528-1543.

Blackwell, M., Iacus, S., King, G. \& Porro, G. (2009), 'cem: Coarsened exact matching in stata', The Stata Journal 9(4), 524-546.

Blei, D. M., Ng, A. Y. \& Jordan, M. I. (2003), 'Latent dirichlet allocation', the Journal of Machine Learning Research 3, 993-1022.

Bombardini, M. \& Trebbi, F. (2020), 'Empirical models of lobbying', Annual Review of Economics 12, 391-413.

Capron, L. \& Chatain, O. (2008), 'Competitors' resource-oriented strategies: Acting on competitors' resources through interventions in factor markets and political markets', Academy of Management Review 33(1), 97121.

Carpenter, D. P., Esterling, K. M. \& Lazer, D. M. (2004), 'Friends, brokers, and transitivity: Who informs whom in washington politics?', The Journal of Politics 66(1), 224-246.

Cassiman, B. \& Veugelers, R. (2006), 'In search of complementarity in innovation strategy: Internal r\&d and external knowledge acquisition', Management Science 52(1), 68-82.

Choi, S.-J., Jia, N. \& Lu, J. (2015), 'The structure of political institutions and effectiveness of corporate political lobbying', Organization Science 26(1), 158-179.

Choudhury, P., Wang, D., Carlson, N. A. \& Khanna, T. (2019), 'Machine learning approaches to facial and text analysis: Discovering ceo oral communication styles', Strategic Management Journal 40(11), 1705-1732.

Clough, D. R. \& Piezunka, H. (2020), 'Tie dissolution in market networks: A theory of vicarious performance feedback', Administrative Science Quarterly 65(4), 972-1017.

Cohen, W. M. \& Levin, R. C. (1989), 'Empirical studies of innovation and market structure', Handbook of industrial organization 2, 1059-1107.

Cox Pahnke, E., McDonald, R., Wang, D. \& Hallen, B. (2015), 'Exposed: Venture capital, competitor ties, and entrepreneurial innovation', Academy of Management Journal 58(5), 1334-1360.

de Figueiredo, J. M. \& Kim, J. J. (2004), 'When do firms hire lobbyists? the organization of lobbying at the federal communications commission', Industrial and Corporate Change 13(6), 883-900.

de Figueiredo, J. M. \& Richter, B. K. (2014), 'Advancing the empirical research on lobbying', Annual Review of Political Science 17, 163-185.

de Figueiredo, J. M. \& Tiller, E. H. (2001), 'The structure and conduct of corporate lobbying: How firms lobby the federal communications commission', Journal of Economics \&3 Management Strategy 10(1), 91-122. 
Denhardt, R. B. \& Denhardt, J. V. (2000), 'The new public service: Serving rather than steering', Public Administration Review 60(6), 549-559.

Diestre, L., Barber IV, B. \& Santaló, J. (2020), 'The friday effect: Firm lobbying, the timing of drug safety alerts, and drug side effects', Management Science 66(8), 3677-3698.

Dorobantu, S., Kaul, A. \& Zelner, B. (2017), 'Nonmarket strategy research through the lens of new institutional economics: An integrative review and future directions', Strategic Management Journal 38(1), 114-140.

Dosi, G. (1982), 'Technological paradigms and technological trajectories: a suggested interpretation of the determinants and directions of technical change', Research policy 11(3), 147-162.

Drutman, L. (2015), The business of America is lobbying: How corporations became politicized and politics became more corporate, Oxford University Press.

Dushnitsky, G. \& Shaver, J. M. (2009), 'Limitations to interorganizational knowledge acquisition: The paradox of corporate venture capital', Strategic Management Journal 30(10), 1045-1064.

Edelman, L. B. \& Suchman, M. C. (1997), 'The legal environments of organizations', Annual Review of Sociology 23(1), 479-515.

Eggers, J. P. (2012), 'Falling flat: Failed technologies and investment under uncertainty', Administrative Science Quarterly 57(1), 47-80.

Ewens, M. \& Marx, M. (2018), 'Founder replacement and startup performance', The Review of Financial Studies 31(4), 1532-1565.

Farrell, J. \& Simcoe, T. (2012), 'Choosing the rules for consensus standardization', The RAND Journal of Economics 43(2), 235-252.

Fernandez, R. M. \& Gould, R. V. (1994), 'A dilemma of state power: Brokerage and influence in the national health policy domain', American Journal of Sociology 99(6), 1455-1491.

Figueiredo, F. \& Andrade, N. (2019), Quantifying disruptive influence in the allmusic guide., in 'ISMIR', pp. 832-838.

Fleming, L. (2001), 'Recombinant uncertainty in technological search', Management Science 47(1), 117-132.

Fleming, L. \& Sorenson, O. (2004), 'Science as a map in technological search', Strategic Management Journal 25(8-9), 909-928.

Funk, R. J. (2014), 'Making the most of where you are: Geography, networks, and innovation in organizations', Academy of Management Journal 57(1), 193-222.

Funk, R. J. \& Hirschman, D. (2014), 'Derivatives and deregulation: Financial innovation and the demise of glass-steagall', Administrative Science Quarterly 59(4), 669-704.

Funk, R. J. \& Hirschman, D. (2017), 'Beyond nonmarket strategy: Market actions as corporate political activity', Academy of Management Review 42(1), 32-52.

Funk, R. J. \& Owen-Smith, J. (2017), 'A dynamic network measure of technological change', Management Science 63(3), 791-817.

Furman, J. L. \& Teodoridis, F. (2020), 'Automation, research technology, and researchers' trajectories: Evidence from computer science and electrical engineering', Organization Science 31(2), 330-354.

Ganco, M. (2013), 'Cutting the gordian knot: The effect of knowledge complexity on employee mobility and entrepreneurship', Strategic Management Journal 34(6), 666-686. 
Ganco, M., Ziedonis, R. H. \& Agarwal, R. (2015), 'More stars stay, but the brightest ones still leave: Job hopping in the shadow of patent enforcement', Strategic Management Journal 36(5), 659-685.

Gao, M., Leung, H. \& Qiu, B. (2021), 'Organization capital and executive performance incentives', Journal of Banking \& Finance 123, 106017.

Geels, F. W. (2004), 'From sectoral systems of innovation to socio-technical systems: Insights about dynamics and change from sociology and institutional theory', Research Policy 33(6-7), 897-920.

Geels, F. W., Sareen, S., Hook, A. \& Sovacool, B. K. (2021), 'Navigating implementation dilemmas in technology-forcing policies: A comparative analysis of accelerated smart meter diffusion in the netherlands, uk, norway, and portugal (2000-2019)', Research Policy 50(7), 104272.

Geels, F. W., Sovacool, B. K., Schwanen, T. \& Sorrell, S. (2017), 'Sociotechnical transitions for deep decarbonization', Science 357(6357), 1242-1244.

Grandy, J. B. \& Hiatt, S. R. (2020), 'State agency discretion and entrepreneurship in regulated markets', Administrative Science Quarterly 65(4), 1092-1131.

Grömping, U. (2007), 'Estimators of relative importance in linear regression based on variance decomposition', The American Statistician 61(2), 139-147.

Grossman, G. M. \& Helpman, E. (1994), 'Protection for sale', The American Economic Review 84(4), 833-850.

Grossman, G. M. \& Helpman, E. (2001), Special interest politics, MIT press.

Gulati, R., Nohria, N. \& Zaheer, A. (2000), 'Strategic networks', Strategic Management Journal 21(3), 203-215.

Hall, B. H. \& Ziedonis, R. H. (2001), 'The patent paradox revisited: an empirical study of patenting in the us semiconductor industry, 1979-1995', rand Journal of Economics pp. 101-128.

Hall, R. L. \& Deardorff, A. V. (2006), 'Lobbying as legislative subsidy', American Political Science Review 100(1), 69-84.

Hargadon, A. B. \& Douglas, Y. (2001), 'When innovations meet institutions: Edison and the design of the electric light', Administrative Science Quarterly 46(3), 476-501.

Hausman, J. A., Hall, B. H. \& Griliches, Z. (1984), 'Econometric models for count data with an application to the patents-r\&d relationship'.

Hiatt, S. R. \& Park, S. (2013), 'Lords of the harvest: Third-party influence and regulatory approval of genetically modified organisms', Academy of Management Journal 56(4), 923-944.

Hillman, A. J. \& Hitt, M. A. (1999), 'Corporate political strategy formulation: A model of approach, participation, and strategy decisions', Academy of Management Review 24(4), 825-842.

Hoberg, G. \& Phillips, G. (2016), 'Text-based network industries and endogenous product differentiation', Journal of Political Economy 124(5), 1423-1465.

Holyoke, T. T. (2009), 'Interest group competition and coalition formation', American Journal of Political Science 53(2), 360-375.

Hula, K. W. (1999), Lobbying together: Interest group coalitions in legislative politics, Georgetown University Press.

i Vidal, J. B., Draca, M. \& Fons-Rosen, C. (2012), 'Revolving door lobbyists', The American Economic Review 102(7), 3731.

Iacus, S. M., King, G. \& Porro, G. (2012), 'Causal inference without balance checking: Coarsened exact matching', Political analysis 20(1), 1-24. 
Jaffe, A. B., Trajtenberg, M. \& Henderson, R. (1993), 'Geographic localization of knowledge spillovers as evidenced by patent citations', The Quarterly Journal of Economics 108(3), 577-598.

Jia, N. (2014), 'Are collective political actions and private political actions substitutes or complements? empirical evidence from china's private sector', Strategic Management Journal 35(2), 292-315.

Jia, N. (2018), "The "make and/or buy" decisions of corporate political lobbying: Integrating the economic efficiency and legitimacy perspectives', Academy of Management Review 43(2), 307-326.

Jia, N., Markus, S. \& Werner, T. (2021), 'Theoretical light in empirical darkness: Illuminating strategic concealment of corporate political activity', Academy of Management Review .

Jia, N. \& Mayer, K. (2016), Complementarity in firms' market and political capabilities: An integrated theoretical perspective, in 'Strategy beyond markets', Emerald Group Publishing Limited.

Jones, B. D. (1999), 'Bounded rationality', Annual Review of Political Science 2(1), 297-321.

Jones, B. D. (2003), 'Bounded rationality and political science: Lessons from public administration and public policy', Journal of Public Administration Research and Theory 13(4), 395-412.

Jones, B. D. \& Baumgartner, F. R. (2005), The politics of attention: How government prioritizes problems, University of Chicago Press.

Jones, S. L., Leiponen, A. \& Vasudeva, G. (2020), 'The evolution of cooperation in the face of conflict: Evidence from the innovation ecosystem for mobile telecom standards development', Strategic Management Journal .

Kaplan, S. \& Vakili, K. (2015), 'The double-edged sword of recombination in breakthrough innovation', Strategic Management Journal 36(10), 1435-1457.

Katila, R. \& Chen, E. L. (2008), 'Effects of search timing on innovation: The value of not being in sync with rivals', Administrative Science Quarterly 53(4), 593-625.

Katila, R., Rosenberger, J. D. \& Eisenhardt, K. M. (2008), 'Swimming with sharks: Technology ventures, defense mechanisms and corporate relationships', Administrative Science Quarterly 53(2), 295-332.

Kim, I. S. (2017), 'Political cleavages within industry: Firm-level lobbying for trade liberalization', American Political Science Review 111(1), 1-20.

Kim, I. S. (2018), 'Lobbyview: Firm-level lobbying \& congressional bills database', Unpublished manuscript, MIT, Cambridge, MA. http://web. mit. edu/insong/www/pdf/lobbyview .

Kim, J. H. (2019), 'Is your playing field unleveled? us defense contracts and foreign firm lobbying', Strategic Management Journal 40(12), 1911-1937.

Kim, M. J., Shaver, J. M. \& Funk, R. J. (2022), 'From mass to motion: Conceptualizing and measuring the dynamics of industry clusters', Strategic Management Journal 43(4), 822-846.

Kogan, L., Papanikolaou, D., Seru, A. \& Stoffman, N. (2017), 'Technological innovation, resource allocation, and growth', The Quarterly Journal of Economics 132(2), 665-712.

Krieger, J. L. (2021), 'Trials and terminations: Learning from competitors' r\&d failures', Management Science 67(9), 5525-5548.

Kumar, P., Liu, X. \& Zaheer, A. (2022), 'How much does the firm's alliance network matter?', Strategic Management Journal .

Kumar, P. \& Zaheer, A. (2019), 'Ego-network stability and innovation in alliances', Academy of Management Journal 62(3), 691-716. 
Laumann, E. O. \& Knoke, D. (1987), The organizational state: Social choice in national policy domains, University of Wisconsin Press.

Leahey, E. (2016), 'From sole investigator to team scientist: Trends in the practice and study of research collaboration', Annual Review of Sociology 42, 81-100.

Levin, R. C., Klevorick, A. K., Nelson, R. R., Winter, S. G., Gilbert, R. \& Griliches, Z. (1987), 'Appropriating the returns from industrial research and development', Brookings Papers on Economic Activity 1987(3), 783831.

Lieberman, M. B. \& Montgomery, D. B. (1988), 'First-mover advantages', Strategic Management Journal 9(S1), 41-58.

Mansfield, E. (1985), 'How rapidly does new industrial technology leak out?', The Journal of Industrial Economics pp. 217-223.

Mansfield, E., Schwartz, M. \& Wagner, S. (1981), 'Imitation costs and patents: an empirical study', The Economic Journal 91(364), 907-918.

Marx, M., Strumsky, D. \& Fleming, L. (2009), 'Mobility, skills, and the michigan non-compete experiment', Management Science 55(6), 875-889.

McCaffrey, D. P. (1982), 'Corporate resources and regulatory pressures: Toward explaining a discrepancy', Administrative Science Quarterly pp. 398-419.

McKay, A. \& Yackee, S. W. (2007), 'Interest group competition on federal agency rules', American Politics Research 35(3), 336-357.

McLaughlin, P. A. \& Sherouse, O. (2018), 'Regdata us 3.1 annual (dataset)', QuantGov, Mercatus Center at George Mason University, Arlington, VA .

McLaughlin, P. A. \& Sherouse, O. (2019), 'Regdata 2.2: A panel dataset on us federal regulations', Public Choice 180(1), 43-55.

McLaughlin, P. A., Sherouse, O., Febrizio, M. \& King, M. S. (2020), 'Is dodd-frank the biggest law ever?', Journal of Financial Regulation .

Meier, K. J. (1985), 'Regulation: Politics, bureaucracy, and economics', New York: St. Martin's .

Miller, G. A. \& Charles, W. G. (1991), 'Contextual correlates of semantic similarity', Language and cognitive processes $\mathbf{6}(1), 1-28$.

Navis, C. \& Glynn, M. A. (2010), 'How new market categories emerge: Temporal dynamics of legitimacy, identity, and entrepreneurship in satellite radio, 1990-2005', Administrative Science Quarterly 55(3), 439471.

Niu, L.-Q. \& Dai, X.-Y. T. (2015), 'Learning distributed representations of topics', CoRR, abs/1506.08422 .

North, D. (1990), Institutions, Institutional Change and Economic Performance, Cambridge University Press.

Oberholzer-Gee, F. \& Yao, D. A. (2018), 'Integrated strategy: Residual market and exchange imperfections as the foundation of sustainable competitive advantage', Strategy Science 3(2), 463-480.

Ocasio, W. (1997), 'Towards an attention-based view of the firm', Strategic Management Journal 18(S1), 187206.

Paik, Y., Kang, S. \& Seamans, R. (2019), 'Entrepreneurship, innovation, and political competition: How the public sector helps the sharing economy create value', Strategic Management Journal 40(4), 503-532. 
Park, M. \& Funk, R. (2022), 'Regulation and innovation revisited: How restrictive regulations can promote destabilizing new technologies', Working Paper .

Park, M., Leahey, E. \& Funk, R. (2022), 'The decline of disruptive science and technology', https://arxiv.org/abs/2106.11184.

Raffiee, J. (2017), 'Employee mobility and interfirm relationship transfer: Evidence from the mobility and client attachments of united states federal lobbyists, 1998-2014', Strategic Management Journal 38(10), 2019-2040.

Ranganathan, R., Ghosh, A. \& Rosenkopf, L. (2018), 'Competition-cooperation interplay during multifirm technology coordination: The effect of firm heterogeneity on conflict and consensus in a technology standards organization', Strategic Management Journal 39(12), 3193-3221.

Rehurek, R. \& Sojka, P. (2010), Software framework for topic modelling with large corpora, in 'In Proceedings of the LREC 2010 workshop on new challenges for NLP frameworks', Citeseer.

Ridge, J. W., Ingram, A. \& Hill, A. D. (2017), 'Beyond lobbying expenditures: How lobbying breadth and political connectedness affect firm outcomes', Academy of Management Journal 60(3), 1138-1163.

Rogan, M. (2014), 'Too close for comfort? the effect of embeddedness and competitive overlap on client relationship retention following an acquisition', Organization Science 25(1), 185-203.

Rogan, M. \& Sorenson, O. (2014), 'Picking a (poor) partner: A relational perspective on acquisitions', Administrative Science Quarterly 59(2), 301-329.

Rogge, K. S. \& Reichardt, K. (2016), 'Policy mixes for sustainability transitions: An extended concept and framework for analysis', Research Policy 45(8), 1620-1635.

Rysman, M. \& Simcoe, T. (2008), 'Patents and the performance of voluntary standard-setting organizations', Management Science 54(11), 1920-1934.

Salisbury, R. H. (1990), The paradox of interest groups in Washington-More groups, less clout, Springer.

Scott, W. R. (2013), Institutions and organizations, Vol. 2, Sage Thousand Oaks, CA.

Shi, W., Gao, C. \& Aguilera, R. V. (2021), 'The liabilities of foreign institutional ownership: Managing political dependence through corporate political spending', Strategic Management Journal 42(1), 84-113.

Shorrocks, A. F. et al. (2013), 'Decomposition procedures for distributional analysis: a unified framework based on the shapley value', Journal of Economic Inequality 11(1), 99-126.

Silverberg, R. (1967), Light for the world: Edison and the power industry, Princeton, NJ: Van Nostrand.

Simcoe, T. (2012), 'Standard setting committees: Consensus governance for shared technology platforms', American Economic Review 102(1), 305-36.

Sine, W. D. \& Lee, B. H. (2009), 'Tilting at windmills? the environmental movement and the emergence of the us wind energy sector', Administrative Science Quarterly 54(1), 123-155.

Sovacool, B. K. (2009), 'The importance of comprehensiveness in renewable electricity and energy-efficiency policy', Energy Policy 37(4), 1529-1541.

Stigler, G. J. (1971), 'The theory of economic regulation', The Bell Journal of Economics and Management Science pp. 3-21.

Teece, D. J. (1986), 'Profiting from technological innovation: Implications for integration, collaboration, licensing and public policy', Research Policy 15(6), 285-305. 
Toh, P. K. \& Miller, C. D. (2017), 'Pawn to save a chariot, or drawbridge into the fort? firms' disclosure during standard setting and complementary technologies within ecosystems', Strategic Management Journal 38(11), 2213-2236.

Tushman, M. L. \& Rosenkopf, L. (1992), 'Organizational determinants of technological change: toward a sociology of technological evolution', Research in Organizational Behavior 14, 311-347.

Ungson, G. R., James, C. \& Spicer, B. H. (1985), 'The effects of regulatory agencies on organizations in wood products and high technology/electronics industries', Academy of Management Journal 28(2), 426-445.

Vasudeva, G., Zaheer, A. \& Hernandez, E. (2013), 'The embeddedness of networks: Institutions, structural holes, and innovativeness in the fuel cell industry', Organization Science 24(3), 645-663.

Weber, K., Heinze, K. L. \& DeSoucey, M. (2008), 'Forage for thought: Mobilizing codes in the movement for grass-fed meat and dairy products', Administrative Science Quarterly 53(3), 529-567.

Werner, T. (2015), 'Gaining access by doing good: The effect of sociopolitical reputation on firm participation in public policy making', Management Science 61(8), 1989-2011.

Wilcox, C. \& Shepherd, W. G. (1975), Public policies toward business, Richard D. Irwin.

Williamson, O. (1985), The Economic Institutions of Capitalism: Firms, Markets, Relational Contracting, Free Press.

Williamson, O. (1996), The Mechanisms of Governance, Oxford University Press.

Wu, L., Wang, D. \& Evans, J. A. (2019), 'Large teams develop and small teams disrupt science and technology', Nature 566(7744), 378-382.

Yackee, J. W. \& Yackee, S. W. (2006), 'A bias towards business? assessing interest group influence on the us bureaucracy', The Journal of Politics 68(1), 128-139. 
Figure 1: Operationalizing Knowledge leakage This figure provides a visual scheme of the novel measure. Intuitively, the measure is a count of highly similar patents from other firms. Similarity between patents is computed using a machine learning technique, Doc2Vec, on the nouns of patent abstracts. Nouns are the focus since technological components, in which technological knowledge is embedded, are objects or ideas; objects and ideas are both likely to be represented by nouns in patent abstracts. Furthermore, recognizing that the patent system is in part designed to prevent expropriation but at the same time imperfect in eliminating expropriation, the measure conservatively determines the window of time in which imitative patenting by other firms is most likely to be the result of knowledge leakage during lobbying. See Dependent Variable section for further details about the operationalization approach and Appendix A for more information about the Doc2Vec analysis.

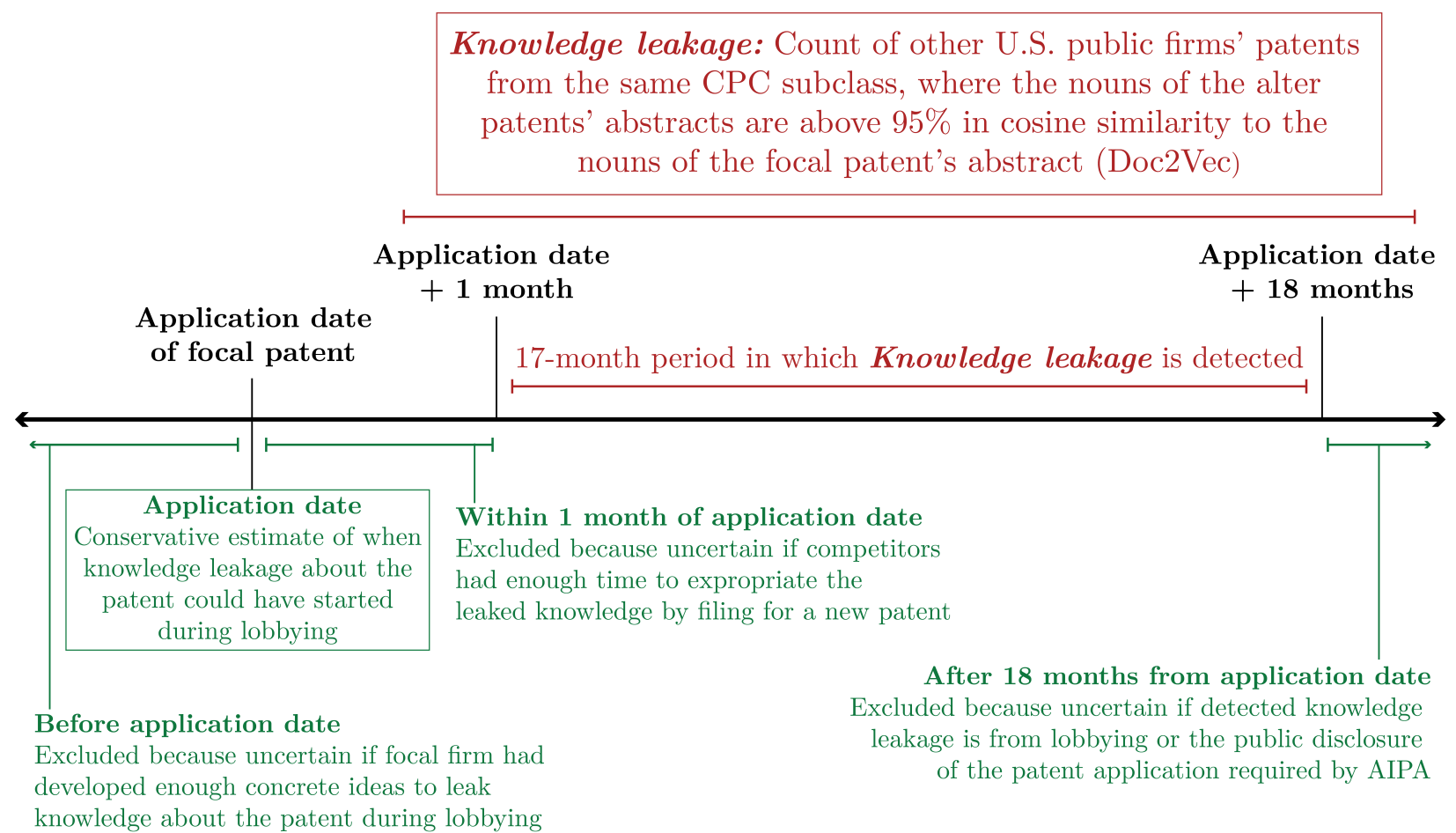


Table 1: Summary statistics

\begin{tabular}{|c|c|c|c|c|c|c|}
\hline Variable & $N$ & Mean & $\mathrm{SD}$ & Min & Max & Level of measurement \\
\hline $\begin{array}{l}\text { Dependent variable } \\
\text { Knowledge leakage }\end{array}$ & 20,636 & 22.47 & 44.09 & 0 & 1,046 & Patent \\
\hline $\begin{array}{l}\text { Independent variables } \\
\text { Lobbying for innovation (dummy) } \\
\text { Lobbying for innovation logged (amount total) } \\
\text { Lobbying for innovation logged (amount oustsourced) } \\
\text { Lobbying for innovation logged (amount inhouse) }\end{array}$ & $\begin{array}{l}20,636 \\
20,636 \\
20,636 \\
20,636\end{array}$ & $\begin{array}{l}0.32 \\
3.86 \\
3.31 \\
2.85\end{array}$ & $\begin{array}{l}0.47 \\
5.73 \\
5.14 \\
5.29\end{array}$ & $\begin{array}{l}0 \\
0 \\
0 \\
0\end{array}$ & $\begin{array}{c}1 \\
15.10 \\
13.38 \\
15.06\end{array}$ & $\begin{array}{l}\text { Firm x Year } \\
\text { Firm x Year } \\
\text { Firm x Year } \\
\text { Firm x Year }\end{array}$ \\
\hline $\begin{array}{l}\text { Controls } \\
\text { Strategic alliance } \\
\text { Noncompete change } \\
\text { Patents from same state } \\
\text { Competition } \\
\text { Revenue } \\
\text { Firm patent count } \\
\text { Patent novelty } \\
\text { Subclass patent impact } \\
\text { Patent leakage alter ratio }\end{array}$ & $\begin{array}{l}20,636 \\
20,506 \\
20,506 \\
20,401 \\
20,636 \\
20,636 \\
20,157 \\
20,636 \\
20,636\end{array}$ & $\begin{array}{c}0 \\
0 \\
41.04 \\
4.41 \\
8,453.16 \\
368.72 \\
0.03 \\
4.35 \\
1.38\end{array}$ & $\begin{array}{c}0.03 \\
0.07 \\
57.40 \\
9.84 \\
15,656.48 \\
342.10 \\
0.17 \\
3.21 \\
0.44\end{array}$ & $\begin{array}{c}0 \\
-1 \\
1 \\
1 \\
0 \\
1 \\
-1 \\
0 \\
0.08\end{array}$ & $\begin{array}{c}1 \\
1 \\
318 \\
88.88 \\
59,985 \\
1,352 \\
1 \\
74 \\
10\end{array}$ & $\begin{array}{c}\text { Firm X Year } \\
\text { Firm X Year } \\
\text { Firm X Year } \\
\text { Firm X Year } \\
\text { Firm X Year } \\
\text { Firm X Year } \\
\text { Patent } \\
\text { Subclass X Year } \\
\text { Patent }\end{array}$ \\
\hline
\end{tabular}

Notes: This table provides the summary statistics for the variables used in the regression to test Hypothesis 1 and 2. 
Table 2: Lobbying for innovation and knowledge leakage (Hypothesis 1)

\begin{tabular}{|c|c|c|c|c|}
\hline & \multicolumn{4}{|c|}{ Dependent Variable: Knowledge leakage } \\
\hline & \multicolumn{3}{|c|}{ Sample: All patents } & \multirow{2}{*}{$\frac{\text { Sample: Matched patents }}{(4)}$} \\
\hline & $(1)$ & $(2)$ & $(3)$ & \\
\hline Lobbying for innovation (dummy) & $\begin{array}{c}0.7505^{* * *} \\
(0.0268)\end{array}$ & $\begin{array}{c}0.5062^{* * *} \\
(0.0411)\end{array}$ & $\begin{array}{c}0.1520^{* * *} \\
(0.0289)\end{array}$ & $\begin{array}{c}0.4349^{* * *} \\
(0.0784)\end{array}$ \\
\hline$N$ & 20,636 & 19,847 & 19,658 & 4,105 \\
\hline Controls & No & Yes & Yes & No \\
\hline Application year FE & No & No & Yes & No \\
\hline CPC subclass FE & No & No & Yes & No \\
\hline \multicolumn{5}{|c|}{ Margins as Lobbying for innovation (dummy) changes from 0 to 1} \\
\hline Imitative patents & +19 & +11 & +4 & +14 \\
\hline Percentage of mean & $+111 \%$ & $+74 \%$ & $+21 \%$ & $+58 \%$ \\
\hline
\end{tabular}

Notes: The models above estimate the extensive margins of lobbying for innovation based on a Poisson specification for all patents with fixed effects (Models 1 to 3) as well as a subsample of patents from coarsened exact matching (Iacus et al. 2012) (Model 4). Results indicate that lobbying firms' patents are associated with $4(21 \%)$ more imitative patents than the patents of non-lobbying firms (Model 3). Overall, these results provide support for Hypothesis 1. Robust standard errors in parentheses; $p$-values correspond to two-tailed tests.

${ }^{*} p<0.05 ;{ }^{* *} p<0.01 ;{ }^{* * *} p<0.001$ 
Table 3: Outsourced vs. inhouse lobbying and knowledge leakage (Hypothesis 2)

\begin{tabular}{|c|c|c|c|}
\hline & \multicolumn{3}{|c|}{ Dependent Variable: Knowledge leakage } \\
\hline & \multicolumn{3}{|c|}{ Sample: All patents } \\
\hline & Total & Outsourced & Inhouse \\
\hline & $(1)$ & $(2)$ & (3) \\
\hline Lobbying for innovation logged (amount) & $\begin{array}{c}0.0040 \\
(0.0098)\end{array}$ & $\begin{array}{c}0.0252^{* *} \\
(0.0077)\end{array}$ & $\begin{array}{l}-0.0179 \\
(0.0112)\end{array}$ \\
\hline$N$ & 19,639 & 19,639 & 19,639 \\
\hline Controls & Yes & Yes & Yes \\
\hline Application year FE & Yes & Yes & Yes \\
\hline CPC subclass FE & Yes & Yes & Yes \\
\hline Firm FE & Yes & Yes & Yes \\
\hline \multicolumn{4}{|c|}{ Margins as Lobbying for innovation logged (amount) increases from $\$ 0$ to $\$ 100,000$} \\
\hline Imitative patents & +1 & +7 & -4 \\
\hline Percentage of mean & $+5 \%$ & $+30 \%$ & $-19 \%$ \\
\hline
\end{tabular}

Notes: The models above estimate the intensive margins of lobbying for innovation based on a Poisson specification with fixed effects. Results indicate that within a firm, increasing outsourced lobbying from $\$ 0$ to $\$ 100,000$ is associated with 7 (30\%) more imitative patents (Model 2). However, inhouse lobbying is not positively linked to knowledge leakage (Model 3). Overall, these results provide support for Hypothesis 2 (see Figure 2). Robust standard errors in parentheses; $p$-values correspond to two-tailed tests.

${ }^{*} p<0.05 ;{ }^{* *} p<0.01 ;{ }^{* *} p<0.001$

Figure 2: Coefficient plots of outsourced vs. inhouse lobbying This figure plots the $95^{\text {th }}$ percentile confidence intervals of the coefficients from Table 3, Models 2 and 3, to directly compare their magnitudes. The point estimate of the coefficient from Model 2, 0.0252 (circle), is greater than the point estimate from Model 3, -0.0179 (square). In addition, while the coefficient from Model 2 is positive and significant, the coefficient from Model 3 is not statistically different from 0 . More importantly, the lower bound of the estimate from Model 2 is greater than the upper bound of the estimate from Model 3, suggesting that the coefficient of outsourced lobbying is statistically larger than that of inhouse lobbying. These results are consistent with Hypothesis 2.

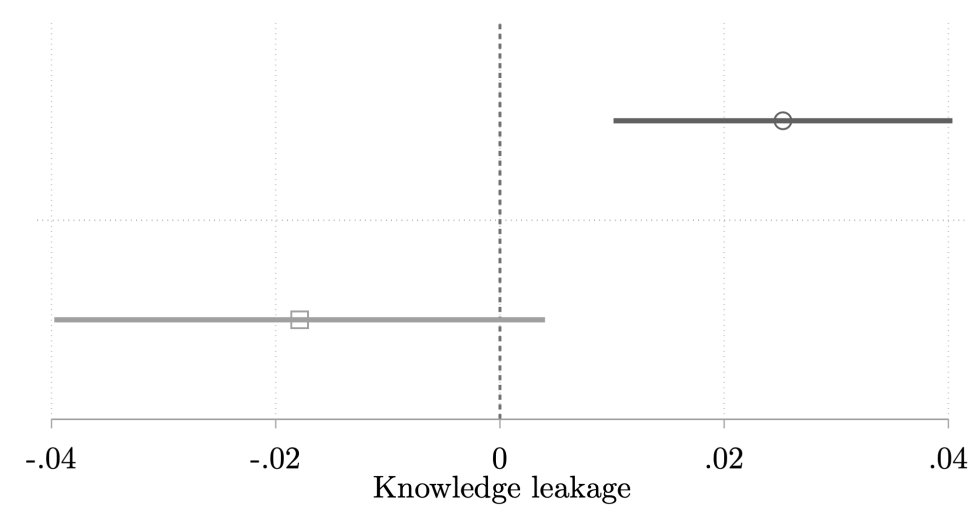

$\bigcirc$ Model 2: Lobbying for innovation logged (amount outsourced)

$\square$ Model 3: Lobbying for innovation logged (amount inhouse) 
Table 4: Leakage of knowledge and financial value of patents (Supplementary Analysis)

\begin{tabular}{lccc}
\hline & \multicolumn{3}{c}{ Dependent Variable: Financial value } \\
\cline { 2 - 4 } & \multicolumn{3}{c}{ Sample: All patents } \\
\cline { 2 - 4 } & $(1)$ & $(2)$ & $(3)$ \\
\hline Knowledge leakage & $-0.0235^{* * *}$ & $-0.0102^{* * *}$ & $-0.0070^{* *}$ \\
& $(0.0026)$ & $(0.0029)$ & $(0.0026)$ \\
\hline$N$ & 20,636 & 20,636 & 20,636 \\
\hline Controls & No & Yes & Yes \\
Application year FE & No & No & Yes \\
CPC subclass FE & No & No & Yes \\
Firm FE & No & No & Yes \\
\hline \multicolumn{1}{c}{ Margins as Knowledge leakage increases from 0 to 7} \\
Value of patent & $-\$ 117,000$ & $-\$ 72,000$ & $-\$ 49,000$ \\
Percentage of mean & $-1.08 \%$ & $-0.66 \%$ & $-0.45 \%$ \\
\hline
\end{tabular}

Notes: Based on an OLS specification with fixed effects, the models above explore whether Knowledge leakage is capturing a negative consequence of lobbying as I have theorized or an erroneous positive outcome resulting from firms' strategic behavior. The dependent variable, Financial value of patents, is from Kogan et al. (2017). I find a robust negative association. In particular, when the number of imitative patents increase from 0 to 7 , the value of the patent decreases by $\$ 49,000(0.45 \%)$ (Model 3$)$. This provides additional support for my theoretical argument and alleviates concerns of a potential alternative explanation stemming from a measurement error. Robust standard errors in parentheses; $p$-values correspond to two-tailed tests.

${ }^{*} p<0.05 ;{ }^{* *} p<0.01 ;{ }^{* * *} p<0.001$ 
Table 5: Variation in lobbying explained by patent and other factors (Supplementary Analysis)

\begin{tabular}{|c|c|c|c|}
\hline & \multirow{2}{*}{\multicolumn{3}{|c|}{$\begin{array}{c}\text { Shapley Values of } \\
\text { Lobbying for innovation logged (amount) } \\
\text { Sample: All patents }\end{array}$}} \\
\hline & & & \\
\hline & Total & Outsourced & Inhouse \\
\hline & (1) & $(2)$ & $(3)$ \\
\hline Patent novelty & $0.00 \%$ & $0.03 \%$ & $0.03 \%$ \\
\hline Patent impact & $0.03 \%$ & $0.02 \%$ & $0.03 \%$ \\
\hline Patent financial value & $1.12 \%$ & $1.03 \%$ & $0.98 \%$ \\
\hline Revenue & $31.42 \%$ & $30.23 \%$ & $37.30 \%$ \\
\hline Firm fixed effects & $64.02 \%$ & $62.16 \%$ & $55.56 \%$ \\
\hline Year fixed effects & $1.43 \%$ & $1.70 \%$ & $2.44 \%$ \\
\hline
\end{tabular}

Notes: The table above presents the relative contributions of each factor in explaining variations in lobbying based on Shapley-Owen decomposition. The results suggest that patent characteristics together explain less than $2 \%$ of the variation across all measures of lobbying, implying that firms do not coordinate their lobbying decisions and patent applications. This provides additional support for the proposed theory by demonstrating that reverse causality is unlikely. 


\section{Appendix}

\begin{tabular}{lll}
\hline Section & Description & Category \\
\hline Appendix A & Doc2Vec for Knowledge leakage & Supplemental information \\
\hline Appendix B & CD index & Supplemental information \\
\hline \hline
\end{tabular}




\section{Appendix A Doc2Vec for Knowledge leakage}

I obtained the full text abstracts of all patents that are in my sample from PatentsView. Using the Python package spaCy I preprocessed and tokenized the text. I first removed all punctuation, digits, and spaces. I also removed words shorter than two characters and longer than 100 characters. My aim is to focus on the knowledge embodied in the set of technological components that are used in the patent. Based on the assumption that components - or physical objects or conceptions - are likely to be represented by nouns than other parts of speech, I focused on words that were tagged as nouns by spaCy in the abstracts.

After tokenzing the abstract text as described above, two tasks remained. I first needed to quantitatively measure knowledge embodied in each patent using the collection of nouns found in the patent abstract. Then based on this quantitative measure of the knowledge used in each patent, I needed to compute the similarity between all the sample abstracts.

For the first step, the standard deep learning procedure of vectorizing each noun requires three neural network that consists of an input, hidden, and an output layer. In this case, the input layer is the set of nouns extracted from the patent abstracts. The hidden layer defines each word from the input layer based on other words that appear close to the focal word. It trains itself to provide the most accurate assignment using the input layer. Then the output layer represents the assignment of nouns as well as each patent abstract (based on the collection of nouns used in the abstract) in a 100-dimension vector space, or "embeddings." For this first step, I used all patent abstracts that were available on PatentsView, including those outside my sample year, because having a larger input layer is more likely to lead to an accurate embedding of each patent abstract. Thereafter, with the embedding of each patent abstract in hand, I calculated the pairwise Cosine distance between a focal patent and other patents applied by other firms within the same CPC subclass.

Doc2Vec is a recently developed Natural Language Processing techniques that incorporates a "deep learning" procedure to create vector space models. Latent Dirichlet Allocation (LDA) (Blei, Ng \& Jordan 2003) is another vector space model that has been used in recent innovation work (e.g., Kaplan \& Vakili 2015, Choudhury, Wang, Carlson \& Khanna 2019), mainly to categorize the content of documents based on the overall topic represented by each document. LDA infers the content of documents by considering the probability of words occurring together across documents. However, LDA makes two restrictive assumptions. Fist, LDA assumes that the total number of topics appearing across all documents is known. Second, the order in which words appear are not considered. Doc2Vec is a technique developed to take into consideration the semantics of words by capturing where in the document a specific word is embedded with respect to other words (Niu \& Dai 2015). This approach is based on an established view in linguistics which suggests that similar words appear in similar contexts (Miller \& Charles 1991). Doc2Vec, therefore, makes no assumptions about the number of categories that may exist across all documents but takes into explicit consideration where in the documents specific words tend to appear to capture the meaning of specific words. Overall, while LDA may be suitable for categorizing documents when the number of topics are known and the actual meaning of words are not important, Doc2 Vec has significant performance advantages in capturing the similarity of content across documents based on the meaning of words as they are used (Rehurek \& Sojka 2010, Niu \& Dai 2015, Baroni, Dinu \& Kruszewski 2014). 


\section{Appendix B CD index}

$C D_{t}$ for a focal patent (" $f$ "), which references a collection of prior patents (" $b$ "), varies over time as subsequent patents (" $i$ ") that references only the focal patent, only the prior patents cited by the focal patent, or both are granted. $f$ and $b$ are fixed once the focal patent is granted, however $C D_{5}$ varies over time as future patents $i$ 's are granted. The exact equation of $C D_{t}$ is as follows:

$$
C D_{5}=\frac{1}{n} \sum_{n=i}^{n} 2 f_{i t} b_{i t}+f_{i t},
$$

where $n$ is the total number of works that cite either the focal patent, its predecessors, or both. The index ranges from -1 to 1 with values between 0 to 1 indicating destabilizing patents and -1 to 0 indicating consolidating patents. The CD index has been used in a wide variety of prior studies across sociology, science of science, computer science, and even musicology. (Leahey 2016, Azoulay, Fons-Rosen \& Graff Zivin 2019, Figueiredo \& Andrade 2019, Wu, Wang \& Evans 2019, Andrade, Figueiredo, Silva \& Morais 2020, Park et al. 2022). 